University of Louisville

ThinkIR: The University of Louisville's Institutional Repository

Electronic Theses and Dissertations

$5-2007$

\title{
What to make of race? : a content analysis of the use of race in health research.
}

Oliver Eugene Rollins Jr.

University of Louisville

Follow this and additional works at: https://ir.library.louisville.edu/etd

\section{Recommended Citation}

Rollins, Oliver Eugene Jr., "What to make of race? : a content analysis of the use of race in health research." (2007). Electronic Theses and Dissertations. Paper 1229.

https://doi.org/10.18297/etd/1229

This Master's Thesis is brought to you for free and open access by ThinkIR: The University of Louisville's Institutional Repository. It has been accepted for inclusion in Electronic Theses and Dissertations by an authorized administrator of ThinkIR: The University of Louisville's Institutional Repository. This title appears here courtesy of the author, who has retained all other copyrights. For more information, please contact thinkir@louisville.edu. 


\title{
WHAT TO MAKE OF RACE?: \\ A CONTENT ANALYSIS OF THE USE OF RACE IN HEALTH RESEARCH
}

\author{
By \\ Oliver Eugene Rollins, Jr. \\ B. S. University of Houston, 2005
}

\begin{abstract}
A Thesis
Submitted to the Faculty of the

Graduate School the University of Louisville

for the Degree of
\end{abstract}

Master of Arts

Department of Pan-African Studies

University of Louisville

Louisville, Kentucky

May 2007 
UNDERSTANDING THE USE OF RACE IN HEALTH RESEARCH:

A CONTENT ANALYSIS

$$
\text { By }
$$

Oliver Eugene Rollins, Jr.

B.S. University of Houston, 2005

A Thesis Approved on

April 10, 2007

By the following Thesis Committee:

Thesis Director 


\section{DEDICATION}

This thesis is dedicated in the loving memory of my great-grandmother and grandfather

Ms. Velma "Big Momma" Berry

and

Mr. Jessie Lee "Poppa” Rollins 


\section{ACKNOWLEDGEMENTS}

I would like to thank my thesis advisor, Dr. Theresa Rajack-Talley, for her patience and guidance. I would also like to thank my other committee members, Dr. Clarence Talley and Dr. Ricky L. Jones, for their, time, encouragement, and knowledge. I would also like to express my thanks to the Department of Pan-African Studies and the African American Studies Program at the University of Houston, for their continued support. Also, thanks to my family and friends in both Houston and Louisville for your encouragement. 


\section{ABSTRACT \\ UNDERSTANDING THE USE OF RACE IN HEALTH RESEARCH: \\ A CONTENT ANALYSIS \\ Oliver Eugene Rollins, Jr.}

May 12, 2007

Using content analysis, this study examines the use of race in health related journal articles from 2000 to 2005. Each of the articles pertained to African Americans and either access to health or quality of health. Selected articles for review were examined in order to gain an understanding as to how race was measured and if race was conceptualized, the explanation for racial disparities, and the intersection of race and class in health. 
TABLES OF CONTENTS

PAGE

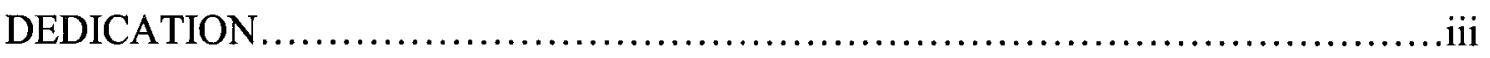

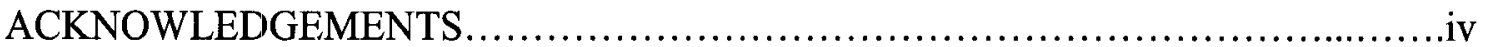

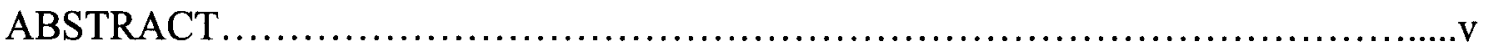

CHAPTER

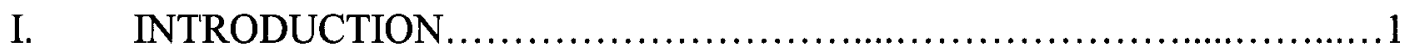

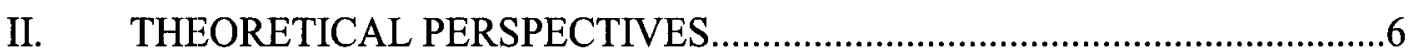

III. THE ROLE OF RACE IN HEALTH RESEARCH...................................25

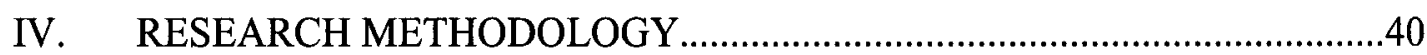

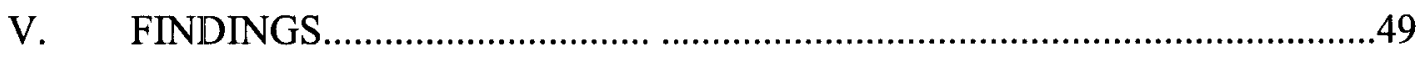

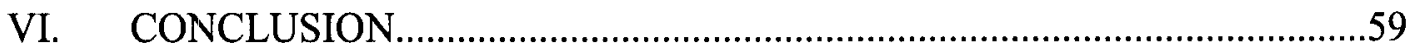

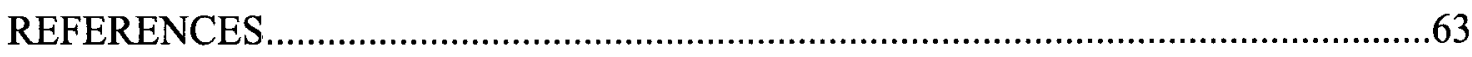

APPENDIX

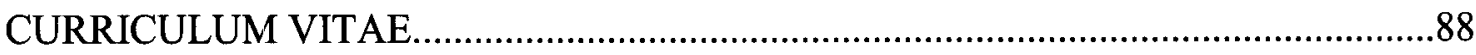




\section{CHAPTER I}

\section{INTRODUCTION}

In the United States, the $20^{\text {th }}$ century was marked by many advances technologically, scientifically, and socially, all of which led to an improvement in overall health of its citizens. These advances contributed to the containment and reduction of many acute communicable diseases and an improvement in the number of years a person lived (Weitz, 2004). For example, the life expectancy for African Americans at the start of the start of the $20^{\text {th }}$ century was 33.5 years for women and for men 32.5 years, and by the start of the $21^{\text {st }}$ century life expectancy had increased to 75.9 and 68.9 respectively (CDC, 2006). However, African American life expectancy is still behind that life expectancy of white females, 80.4 years, and males 75.3 years. Therefore, even with these extraordinary improvements in life expectancy, America has failed to eliminate the persisting dilemma of inequity in health care based on race.

Some researchers argue that the disparity in health is, in part, a result of African Americans, and other minorities, being placed historically at the bottom of society's hierarchical structure (Byrd and Clayton, 2000a, 2000b; Krieger, 2001; Randall, 2006; Semmes, 1996). For example, W. Michael Byrd and Linda A. Clayton (2000a, 2000b) contend that historical barriers based upon race can be traced back to enslavement. Moreover, these barriers help construct and maintain the present state of inequity in African American health. Some of these barriers include factors such as: limitations that 
impede access to health care facilities, the quality of health treatment received by African Americans, and the degree and amount of racism that African Americans are forced to endure on a daily basis (Byrd and Clayton, 2000a, 2000b; Randall, 2006).

An increasing number of publications on race in health related journals have highlighted greater awareness of these factors and how they relate to health disparities (Geiger, 2003; Mayberry, Mili and Ofili, 2000). However, the gap in health for African Americans not only continues to persist, but in relation to many illnesses and conditions, the gap has continued to expand. Within the body of literature health researchers offer an array of biological, social, and cultural explanations to account for this persisting health dilemma. A critical analysis of the research shows that there are ambiguous definitions, uses, and measurements of race (Dressler, Oths, and Gravlee, 2005; Griffith, Moy, Reischl, and Dayton, 2006). Chris Smaje (2000a, 2000b) notes that the concept of race has been consistently marginalized or misunderstood in health research which has had an effect on how the concept has been measured or if it is even taken into account. Therefore, the question that arises is, how should researchers effectively study the concept of race in relation to health disparities?

In 1994, David Williams approached this question by examining the use or race in heath research journal articles. Williams analyzed articles from the year 1966-1990 in order to determine how race was used, how the term was defined, and whether race was understood as a biological or social construct. Williams found that race was many times used interchangeably with the term ethnicity. Furthermore, Williams also observed that in a large majority of the articles published during this time race was used in their articles, not as a focus, but as a variable used to explain differences in health. As such, these 
articles did not define how they were using race, nor did they give the reasons why racial differences exist or the importance of race.

Since the publication of Williams' work there have been other studies that have employed similar methods to examine the use of race in published research articles. These studies, have attempted to examine the use of race using the same criteria as Williams'1994 report. They explore the dichotomy between race as biological construct versus race as a social construct, the use or race versus ethnicity, and the association between health behavior and race. However, an area that has not been examined in the research literature using this methodology has been the relationship between race and social class.

This thesis plans to explore the use of race by examining the affects of class on race. Since Williams' (1994) publication, and the subsequent publications that have followed, it has become more common for most researchers of health and race to understand race as a social construct. Therefore, it is expected that the articles reviewed for this thesis will also accepted this notion. However, what is less known is whether these articles conceptualize race in relation to social class measures such as, income, educational level, poverty rates, etc. An understanding of race as a social construct does not mean that the affects are race are fully conceptualized. In order to conceptualize the affects of race fully there has to be an understanding of the social class factors that contribute to race. 


\section{PURPOSE OF STUDY}

The objective of this thesis is to better understand how race is used in health research. Specifically, the use of race as a concept in health related research is examined to gain a further understanding of the interrelationship between race and class within the matrix of social stratification.

This study utilizes content analysis to examine how race is treated and how the affects of race are examined in health research. Content analysis is employed to examine published research from 2000-2005 that pertain to two sets of researched literature. Both of the data sets used in this study are limited to articles specific to access to care or quality of health care for African Americans. The first set of articles relates to the relationship between general health inequalities and race, and the second set is specific to inequalities in health for African Americans with various forms of cancer.

This thesis aims to help clarify the importance of using race as a concept in health research. This study takes the position that race must be properly conceptualized in health research if research is to be truly effective at combating racial health inequalities. Furthermore, properly conceptualizing race and fully understanding its effects on health cannot be done without considering, and understanding, the effects of social class.

In the following, CHAPTER 2, the major theoretical contributions to the study of health from medical sociology are outlined. Major themes within the discipline are highlighted as well as relevant contributions from medical anthropology and social epidemiology. This chapter serves as the theoretical lens in which the information collected is analyzed. The next chapter, CHAPTER 3, The Role of Race in Health Research, gives a review of literature on race and health inequalities. It highlights five 
central models used within health research to explain the racial health disparities: the racial-genetic model, health-behavior model, socioeconomic status model, psychosocial model, and structural-constructivist model.

In CHAPTER 4, Research Methodology, the approaches and objectives of the study are described. It also discusses the research design and sampling procedures. This includes the selection process, a list of key words and concepts use when searching for studies. This chapter also provides the criteria included in the tables used that are used for the analysis of the journal articles. CHAPTER 5, discusses the relevance of the data collected from the articles, and highlights significant patterns that emerge from the data in relation to the use of race in health studies. The Conclusion, CHAPTER 6, discusses the role of race in health research, how race is used in health research, the importance of measuring race correctly, and the race/class interaction. At the end of this chapter implications for future studies are suggested. 


\section{CHAPTER II}

\section{THEORETICAL PERSPECTIVES}

This chapter is a review of the literature on health, illness, and health care within sociology. It discusses some of the research approaches employed by studies when investigating aspects of health, as well as the theoretical influences of medical sociology. Social theory is a vital part of medical sociology. It serves as the lens through which medical sociologists examine the state of health, and its use is what separates the field from other forms of health research (Cockerham, 2001). A sub-field of sociology, medical sociology, attempts to explain and/or challenge factors within society that construct, or impede well-being.

Some of the main themes within medical sociology include the practice of medicine, the construction of medical knowledge, the role and perceptions of the 'sick', social inequalities in health, and the behavior of groups, institutions, and organizations, all of which help to shape the contours of health and illness within society (Bird, Conrad and Fremont, 2000; Cockerham, 1988; Fox, 1985; Nettleton, 2006; Williams, Gabe and Calnan, 2000; Weitz, 2004). These themes make up medical sociology's unique contribution to the study of health. However, some within the field have noted that the future of medical sociology should incorporate a greater collaboration of work between all fields of health research (Good and Good, 2000; Syme and Yen, 2000). 


\section{RESEARCH APPROACHES}

Many researchers argue that medical sociology will benefit from working with other fields in health research because of the large amount of issues and topics between the fields that overlap. Furthermore, cooperation between disciplines has the ability to both address, and help minimize, the limitations of each other field of study (Good and Good, 2000; Pescosolido and Kronenfeld, 1995; Syme and Yen, 2000). While there are issues and concerns that are shared within the various fields of health research, there are subtle differences in the use of methodology and theory. Medical sociological research explores the relationship between medical sociology, medical anthropology and epidemiology. These three areas of research and are discussed below.

\section{Medical Anthropology}

The major differences between medical sociology and medical anthropology are within the methodological approach. Through ethnographic research, medical anthropologists were some of the first investigators in health to go outside the rigorous boundaries of research set by medical science. Medical anthropologists were also some of the first to deal with the aspect of culture within medical practice, by examining how culture shapes and influences medical practice (Good and Good, 2000). Furthermore, medical anthropologists have also made unique contributions to the understanding of health and healing through their work in the fields of biomedicine, bioscience and biotechnology, clinical narratives, and comparative studies of culture (Good and Good, 2000). 
Through ethnographic studies and clinical narratives, medical anthropology introduced a qualitative aspect of health research. Clinical narratives, as described by Good and Good (2000), are "created between physicians and patients entailing the progression of therapeutic activities and there impact on a patients experience" (p, 382). The advantages of these narratives are two-fold. First, they give the reader an insight to the medical treatment and the state of health of the patient, and second they give the reader an insight of the physician's perspective of the patient. This allows researchers in health the advantage of understanding the role of the physician, his/her expectations of the patient, and an insight into the cultural values that are upheld within the particular medical environment. Cultural values would include differences in language, understanding of health and health practices, or religious beliefs that can influences the way a patient understands the role of a medicine and medical providers.

\section{Epidemiology}

Like medical anthropology, epidemiology is another discipline concerned with health with unique characteristics that link it with many of the issues explored in medical sociology. Epidemiology was one of the first disciplines to move outside of the hospital and clinical settings to explore patterns and distribution of illness within society (Weitz, 2004). The field of epidemiology can be further specialized into the sub-field, social epidemiology. Epidemiology looks at how diseases are distributed and what are the causes of distribution. Social epidemiology essentially includes the same characteristics as epidemiology, but attributes the causes for the distribution of illnesses to social factors. 
Social epidemiology uses social factors to understand the distribution of a particular disease versus medical sociologist who are concerned with social concepts as explained though illnesses (Syme and Yen, 2000). "[Medical] sociologists are fundamentally concerned with social interactions and social process, and epidemiologists are more concerned with the characteristics of individuals which, in aggregate, predispose them to certain diseases" (Nettleton, 2006: 171).

Differences between the two disciplines led some sociologists to accuse epidemiological studies of promoting the idea of surveillance health (Bury, 1998). Surveillance health, or medicine, in this context, refers to the tracking schemes utilized by social epidemiologists. The phrase surveillance medicine refers to the use of medical treatment, knowledge, or technology to observed, or track, groups within society (Armstrong, 1995; Bury, 2000, 2005). This would also include measurements and calculations of health factors within society. Prevention techniques to illness are very beneficial to society, but the limitations of prevention techniques are characteristics of surveillance medicine.

Not all share the role of epidemiologists as promoters of surveillance health. Some researchers argue that one of the greatest contributions of epidemiologists is in the area of social stratification (Syme and Yen, 2000). Social epidemiologists see an opportunity to reduce, or control the risk factors related to health by studying the health patterns of higher social classes. The rational behind such an effort is that higher social classes are not plagued by as many social risk factors as the lower classes, therefore by studying the higher classes in society a researcher may narrow down certain risk factors without having to account, or control, for others (Syme and Yen, 2000). 
These three areas, medical sociology, medical anthropology, and social epidemiology would all benefit from a close collaboration in research. Understanding what each discipline uniquely contributes to the others, area of research on health strengthens the potential for work to be done between the fields. Due to the overwhelming social, environmental, and mental affects of diseases, more studies have employed methodological approaches that seek to understand better the role of health in society by assembling a research team from an array of health research areas (Pescosolido and Kronenfeld, 1995).

Furthermore, it seems that this trend has gained popularity in recent years within many of the health research and public health journals. It has become difficult, if not impossible, many times to separate clearly each discipline's contribution within health studies. This approach has strengthened health research and the potential of researchers to combat accurately the growing problems that surround health. A close relationship among all the disciplines in health care would not only produce new, and/or better developed, methodology, but also theoretical understanding of the link between social forces and health.

\section{THEORETICAL PERSPECTIVES IN SOCIOLOGY}

Theory is one of the most important analytical tools utilized within sociology and throughout various other disciplines in higher academia. "Theory is a process of developing ideas that can allow us to explain how and why events occur" (Turner, 1986: 4). Although the roots of modern theory date back to the start of the nineteenth century, early theoretical works have, and continue to, influence the present, and future, work 
done by sociologists (Ashley and Orenstein, 2001; Kivisto, 2003; Lemert, 2004). This section will present some of the classic theories in sociology that have influenced medical sociology, and some of the more contemporary theoretical contributions advanced by the sub-field.

\section{Structural-Functionalism}

Structural-functionalism is a perspective within sociology that views the makeup of society as a system of interrelated parts each having a specific function that contributes to the overall functioning of the society (Lemert, 2004; Thomas and Hickey, 2002). Structural-functionalists argue that society works much like a human body in which homeostasis, or stability will occur without intervention; society, like the body, will regulate and mend itself (Cockerham, 1988, 2001; Bird et al., 2000; Coe, 1970; Nettleton, 2006; Shilling, 2002; Weitz, 2004). The work of Emile Durkheim, although occurring before the development of structural-functionalism, became a fundamental influence for those theorists who helped construct the structural-functionalist paradigm.

During his time Durkheim was one of the few sociologist who took an interest in issues pertaining to the health of the population. Durkheim's 1897 study, Suicide: A Study in Sociology, demonstrated a shift in thinking concerning problems of health in society (Cockerham, 2001). Durkheim's work implied that the rate of suicides was directly related to the level of social cohesion present within society. He identified three major types of suicide: altruistic, anomic, and egoistic all of which played a part in society's build by constructing, or shaping, humanity's functional responses (Cockerham, 2001; Durkheim, 1951). 
At levels of high social cohesion, altruistic suicides were seen. Conversely, anomic suicides were observed when there was inadequate social cohesion. Anomic refers to the term anomie, which means "a state of social strain, normative confusion or rapid change in the norms, when people's behavior is no longer restrained by conventional norms" (Thomas and Hickey, 2002: 173). For Durkheim, suicide during a state of anomie was the result of a lack of social cohesion that deprived people of the necessary laws, or norms, needed in order to operate productively in society (Thomas and Hickey, 2002). Durkheim observed egoistic suicides during a state of optimal social cohesion. He suggested that this type of suicide occurred as a result of an individual's lack of integration into society. This type of suicide can be observed during high or low levels of social cohesion. These suicides occur because of an individual not being able to integrate his/herself into society or within social circles adequately (Durkheim, 1951; Thomas and Hickey, 2002). Durkheim's contribution played an important role in understanding the influence of societal factors on the state of health, and in the process, it laid the groundwork for the use of structural-functionalism within medical sociology, and health research.

One of most important theoretical works for structural-functionalism came from Talcott Parsons, in his book The Social System. Parsons' work introduced the concept of the "sick role" which can be seen as the societal expectations of those who are deemed sick. Rose Weitz (2004) defines the sick role as, "social expectations regarding how society should view sick people and how sick people should behave" (p 141). The introduction of this work marked the first time in which the physician's role was viewed as a source of social control. In addition, for the first time, sickness was seen in a 
different light, as a deviant behavior. Deviant behavior is a violation of, or move away from, the normal aspects that constitute a functioning human society (Conrad and Schneider, 1980; Thomas and Hickey, 2002).

Parsons summarized the idea of the sick role in four aspects (Parsons, 1951). Parsons maintained that illness provided a legitimate exemption from social duty for a person. For Parsons being sick was a seen as a dysfunctional state in society. When a person is sick, they threaten the stability of society due to the power they have to evade their social duties and responsibilities. Therefore, like other structural-functionalist explanations of society, to much, or little, of any condition is viewed as threatening and undesirable for the stability of society. Structural-functionalists state that stability, and growth, within a society is displayed only when some type of balanced is achieved between the two extremes of a condition (Weitz, 2004).

Parsons also states that when a person is sick the individual loses the power to control her/his illness. Thus, Parsons proposed that while a sick person has the power to disrupt society s/he is rendered powerless to control her/his manifestation of an illness. Parson noted that being sick is an undesirably condition and one should try to improve themselves as quickly as possible. Since he declared in postulate number two that a person is has no control of his/her illness, his last postulate helps clarify how, as stated in postulate number three, a person is to get help in order to relive his/her state of illness. The last aspect states that a sick person should seek help from a physician or medical provider.

Parsons work on the sick role ultimately placed what was previously only understood, or conceptualized, in medical circles into a social context, which could be 
explained using sociological theory (Cockerham, 1988, 2001; Nettleton, 2006; Weitz, 2004). However, despite the argument that many still make for the functionalist perspective within health (Shilling, 2002), Parson's work does not adequately answer the questions surrounding the sociological significance of health (Cockerham, 1988, Nettleton, 2006; Weitz, 2004). As noted by Bird et al. (2000), "Parsons' model was best suited for white middle class person with an acute illness" (p 3).

It should be noted that none of Parsons' suggestions addressed social inequalities such as race, gender, or class; nor how these conditions could impede the process of health care. This is specifically relevant in the case of his last characteristic, which states that a sick person must seek help from a medical professional. This characteristic ignores economic factors that can impinge a patient's ability to pay. The need for medical intervention cannot be suppressed without the proper financial arrangements, namely insurance, in place to pay for such help. Moreover, many who are sick cannot afford the medical treatment needed to live an active life. Then many times, they must choose between medical treatment and other essentials (food, shelter, clothing etc.) for them and their families (Armstrong and Bos, 1992; Williams and Collins, 1995; Williams, 1999). Criticisms similar to these on Parson's sick role eventually extend to the all of structuralfunctionalism and soon other theoretical paradigms arose that challenged the ideas put forth by the functionalist perspective.

\section{Symbolic Interaction}

One of the first tenets of social theory that begin to question the use, and validity, of structural-functionalism was symbolic interaction (Kivisto, 2003). Symbolic interaction was first introduced through the work of George Herbert Mead and later 
through his student Herbert Blumer. Blumer (2003[1962]) states that symbolic interaction has three keys, "Human beings act toward things on the basis of the meanings that they attach to them, the meanings are derived from, or arise out of, interaction with others, and these meanings may be changed or modified through the processes of interaction and interpretation" (Blumer, 2003 [1962]: 243). In contrast to the macro-level explanation of society put forth by structural-functionalist paradigm, symbolic interaction can be described as a hermeneutical theoretical paradigm that views meanings within society from the interaction of individuals with each other (Cockerham, 2001; Thompson and Hickey, 2002).

One of the first works from symbolic interactionism that contributed to medical sociology is from Howard Becker, Anselm Strauss and colleagues. In their book, Boys in White, they provide a sociological understanding of the secluded community of medical schools. The book is a participant observation study that documents the educational training, interactions, and barriers of medical school students (Becker et al, 1961). Later Becker, and then Eliot Freidson in his 1970 publication Profession of Medicine, used the concept of "labeling" to challenge Parsons' sick role (Cockerham, 2001; Nettleton, 2006). William Cockerham (2001) states that, "labeling theory held that deviant behavior is not a quality of the act a person commits but rather is a consequence of the definition applied to that act by others" (p. 8). Therefore, illness, or being sick, becomes deviant behavior only because others react to it as such (Nettleton, 2006). However, labeling theory does not explain how other social factors affect deviance or why individuals act in such a way (Cockerham, 2001; Conrad and Schneider, 1980). 
Freidson also made an important theoretical contribution in his book, Professional Dominance, which was also published in 1970 (Bury, 2000; Cockerham, 1988, 2001). Some of the main themes of medical sociology that are employed when studying the doctor-patient relationship can be found in the work of Freidson (Cockerham, 1988). Renee Fox (1985) describes these themes of medical sociology as: the function and behavior of the sick role and the professional dominance of physicians including their individualism, autonomy, and power over their patients. These topics remain important in the studies of medical sociology. They serve as extension of Parson's work on the sick role and they continue to be modified for further use in health research.

Another important contribution from symbolic interactionism came from the work of Ervin Goffman on mental institutions in his book, Asylums. Goffman introduced the concept of "total institutions" which implied that mental facilities were there own secluded society separated from the wider society (Cockerham, 2001; Thomas and Hickey, 2002; Weitz, 2004). Furthermore, these segregated communities produced what Goffman called mortification. Mortification can be seen as a process of adaptation to life within an institution, in which a person's original image is discarded due to their seclusion from society and replaced by the image or role expected of an inhabitant within institution (Weitz, 2004). Goffman would later use his experience from this study to develop his dramaturgical perspective.

Dramaturgy serves as an analytical tool employed by Goffman, which implies that human behavior is understood by viewing people within society as actors on stage, and that individual see themselves through the eyes of others (Cockerham, 1988, 2001; Kivisto, 2003; Weitz, 2004). Goffman states that there is no real self and that people are 
only actors. Moreover, one could get a clear understanding of society if it is thought of as stage, and the people in society as actors just fulfilling a role (Goffman, 2003).

However, even though symbolic interaction had a great number of contributions to the field of medical sociology, like structural-functionalism, it too has its limitations. Symbolic interactionism does not take into account conflict or power relations, specifically at the macro-level, which influence the choices made in society (Cockerham, 2001; Thomas and Hickey, 2002). A theoretical perspective that attempts to conceptualize the effects of conflict and seek to understand the struggles between institutions, and individuals, for power is the conflict theory paradigm.

\section{Conflict Theory}

Conflict theory, drawing heavily from Karl Marx and Max Weber, maintains that society is best explained by understanding how certain groups are in a continual conflict, or struggle, in order to gain advantages and control. Conflict theory supports the idea that inequality is inevitable in society (Cockerham, 2001; Conrad and Schneider, 1980; Thomas and Hickey, 2002). Like, symbolic interactionism, Conflict theory also challenged the structural-functionalist viewpoint. Conflict theorists claimed that structural-functionalism failed to deal with the conflictual nature of societies (Cockerham, 2001; Turner, 1986). One perspective, Cockerham (2001) argues is that despite its own stance against structural functionalism conflict theory has not been a major contributor to medical sociological theory. Although there has been many attempts by conflict theorists to engage in topics within medical sociology namely, health care delivery and policy, conflict theory fails to explain the occurrence of sickness, or even being healthy, when there is a lack of struggle, conflict, or competition (Cockerham, 
2001). However, a counter argument on conflict theory can be made against

Cockerham's position. The importance of conflict theory for the both the study of health and illness, and in general, is the notion of inequality between groups and social stratification (Thomas and Hickey, 2002).

The study of inequalities in relation to health and the distribution of illness has become a vital point of interest for health care researchers within social sciences (Bury, 2005). The conflict theory viewpoint links inequity within a society to the level of structural inequality (Bury, 2005; Thomas and Hickey, 2002). Thomas and Hickey (2002) state that from a conflict perspective, "the most serious flaws in health care, can be attributed to unequal access to medicine and health care, high cost linked to large profits, bureaucratization and its resulting alienation, and the use of scientific medicine as an ideology to reinforce social inequality" (p. 514). For conflict theorists access to health depends on social class or status, or the ability to pay.

In the United States, the ability to pay for medical care is most commonly available using insurance. The inability to pay for health care, and the lack of health care insurance, disproportionately affect racial minorities, females, and individuals in the lower levels of social classes (Bury, 2005; Lahelma, 2001; Mullahy, Robert, and Wolfe, 2007; Scott, 2007; Smedley, Stith, and Nelson, 2003; Williams and Collins, 1995). Inequality in access to health is tied to the rising cost of health care and this can be at least partially accredited to the greed of capitalist minded bureaucracies that control health care distribution. These controlling bureaucracies would include pharmaceutical companies, insurance companies, and administrations that run hospital and clinics including state and federal governments (Lahelma, 2001; Thomas and Hickey, 2002). 
For conflict theory, studies around the notion of health inequalities can be placed within the framework of social stratification (Bury, 2005; Lahelma, 2001). Social stratification by definition refers to a form of inequity, which hierarchically ranks individuals based on their access to resources (Thomas and Hickey, 2002). When examining social stratification many times these social resources are evaluated by social class, which can be measured by income level, social status, occupational status, wealth, and educational levels (Lahelma, 2001; Williams and Collins, 1995). These determinants have been shown to be directly associated with the state of health of an individual.

Studies have also indicated that a lack of these determinants results in a lower level of health. In contrast, when these determinants are present at higher levels a greater state of overall health is more commonly observed (Bury, 2005; Lahelma, 2001; Mullahy et al., 2007; Scott, 2007; Williams and Collins, 1995).

\section{Post-Structuralism}

As health inequalities continue to persist in society, even with the great number of advancements in health care, some sociologists have tried to address these emerging challenges by exploring the use of more contemporary perspectives in social theory. One of these theoretical perspectives is post-structuralism, which is employed more often in health care research by British sociologists (Nettleton, 2006).

Post-structuralism is described as the use symbols, language, codes and signs, to investigate culture, and it supports the position that individuals are controlled through discourse (Cockerham, 2001). The contributions of Michel Foucault serve as some of the leading works within post-structuralism. Foucault's work examines the intertwined process of power and knowledge, which he deems as inherent in certain locations within 
society. This power/knowledge relationship could be seen in general medical practice, mental health and criminal institutions and in sexuality discourse (Bury, 2000; Cockerham, 2001). In his analysis of medicine, Foucault (1973) stated that medical treatment had two facets, one dealing with the treatment of diseases and the other with the prevention of diseases. In relation to the treatment of disease, Foucault stated that physicians alone possess both the power and control to create medical meaning in relation to treatment for their patients.

Michael Bury (1986) states, "the objects of medical science are not what they appear to be; the stable realities of the human body and disease are in fact 'fabrications' or 'inventions' rather than discoveries" (p. 137). Sara Nettleton (2006) describes this approach taken by physicians as discourse analysis, where medicine's objectives are created by discourse. Foucault used the phrase medical gaze.

What is fundamentally invisible is suddenly offered to the brightness of the gaze... [the gaze] is nothing more than a syntactical reorganization of disease in which the limits of the visible and invisible follow a new pattern, the abyss beneath illness, which was the illness itself, has emerged into the light of language (p. 195).

The medical gaze is a product of observation in which doctors alone are able to diagnose patients through observation. Then, through the use of this discursive practice, doctors are able to formulate causes to explain their patient's aliments. This explanation leads to some type of treatment and, hopefully, the elimination of the harmful pathogens causing the sickness (Bury, 2000; Foucault, 1973; Nettleton, 2006). Foucault's work provides a foundation on which post-structuralism continues to strive on within other areas of social theory including social constructionism. 


\section{Social Constructionism}

Social constructionism may be the most important facet of medical sociology (Bury, 1986; Nettleton, 2006). It is most useful in understanding the use of, and power inherited in, medical knowledge (Nettleton, 2006). This can be illustrated by the stance medical sociologist make in relation to the social construction of illness. Rose Wetiz (2004) states, "illness is a social construction [because] it is something that exists in the world not as an objective condition but because we have defined it as existing" (p. 119). This is not to infer that pathogens do not exist or that a person does not suffer from the infections of pathogens. However, this does imply that society places certain characteristics and exceptions on a person labeled ill.

Medical sociologists make a deliberate distinction between the terms disease and illness, when referring to the specific conditions that plague health. Disease is used when explaining the biological pathogen that infects the organism causing physical signs and symptoms, while illness refers to the society's interpretation, and response to these signs and symptoms (Nettleton, 2006; Weitz, 2004). For medical sociologist the consequences of having an illness can be considered the byproducts of a social constructed concept. Bury (1986) states that the goal of constructionism in medical sociology is to "investigate new ways of relating social structures to experiences, of showing social etiology in disease and illness...tackl[ing] what are perceived as limitations of traditional approaches to medical knowledge, medical treatment and their effects"(p. 150).

\section{Medicalization}

Closely related to the idea of social constructionism is the notion of medicalization. The roots of medicalization come from the symbolic interactionist's 
concept of labeling. Medicalization is the process of labeling a condition as medical, which means it would require medical intervention in order to treat (Weitz, 2004). While medicalization can have its advantages such as a greater awareness of illness and developing treatment for illnesses and conditions, but it can also be considered a source of social control that can produce negative consequences for society (Conrad ad Schneider, 1980).

An example of the negative effects of medicalization can be seen in the increasing number of children diagnosed with "attention deficit disorder" (ADD). ADD seemed to be an answer to the questions concerning the behavior of children who are labeled inattentive, bored, or even hyperactive (Weitz, 2004). In order to treat ADD the drug Ritalin is used, and as the number of ADD cases dramatically increased, pharmaceutical companies were encouraged to produce a significant amount more of the Ritalin. At the same time, this rise in the production of Ritalin was met with more and more children to being diagnosed each year with ADD (Bury, 2005; Weitz, 2004). At times it is hard to tell whether there is a just a growing number of more and more sick children each year, or if the overproduction of Ritalin is influencing more doctors to diagnose a greater number of children as sick (Weitz, 2004). Rose Weitz (2004) notes that in 1998 the number of children diagnosed with ADD had grown to over 5 million, this is more than 5 times the amount of children diagnosed at the start of that decade. While medicalization can inform society of illnesses or conditions such as ADD, it can also produce an adverse effect, making society more dependent on medical treatment (Weitz, 2004). Therefore, it can be stated that the medicalization of problems will not necessarily led to eradication, or even the improvement, of illness within society. Other examples of the effects of 
medicalization can be seen in studies pertaining to the control and use of the body, which is highlighted by the work done in the sociology of the body.

Sociology of the Body

The sociology of the body is also a fast growing area of research in medical sociology (Nettleton, 2006). It continues on the work started by Foucault when exploring sexuality and adds to it the work of feminist theorists (Cockerham, 2001, Nettleton, 2006). Nettleton (2006) highlights five reasons why the body became a focal point of exploration by medical sociologists, and sociology as a whole. The first reason, put forth by much of the feminist literature, is the attempt by women to reclaim control over their bodies. The regulation of the body has been controlled by males, in a male dominated society. One of the most well known examples of this process relates to medicalization of childbirth. As medicine continued to progress through phases, childbirth became associated with the need for medical care. Midwives were no longer seen as having the medical capabilities to deal with delivery, and the health of both mother and child were seen as being much better under the carefully watch of trained doctors, during this time namely male doctors.

Reason two, refers to the technological innovations, in particular those that have to do with human reproduction, such as the human genome project. The third reason, which is closely related to the second, seeks to better understand role of physical appearances and there effects on human behavior. This includes such ideas as staying in shape, eating "right", exercising, and cosmetic alteration from make-up to surgery. The forth point is connected with the concept of aging and the improvement of later life and life expectancy. Nettleton (2006) states that "the graying of society" challenges ideas 
about the ownership of bodies, as people debate the contours of such processes as euthanasia, as well as the demographic trends that makeup of society which have changed as more people are living longer.

The last reason pertains to the ethical issues about the body. Ethical debates include the use of medical research (i.e. stem cell research) and mistreatment of the body smoking, alcohol and drug abuse and consumption. The behavioral explanation in health is many times misconstrued by health researchers who often misuse, and overuse, these behavior explanations in order to explain the causes for inequalities in health between certain groups. These researchers neglect to take into account others factors that can influence adverse health outcomes (Dressler, 1993; Dressler, Oths, and Gravlee., 2005). 


\section{CHAPTER III}

\section{THE ROLE OF RACE IN HEALTH RESEARCH}

The study of the distribution of illness across segments of the population is known as the social pattering of health and is one of the key ways in which medical sociologists study inequalities in health (Bury, 2005). Bruce Link and Jo Phelan (1995) declare that when examining social pattering medical sociologists attempt to clarify the direction of causation between social factors and health, to explain the construction of illness distribution within society. Social patterning of health is usually thought of within the context of different factors that affect an individual's condition within society. These factors include race, class, age, gender, and lifestyle, or behavioral, choices (Weitz, 2004). This chapter will specifically look at one tenet of social pattering, the effects of the affects of race in health research.

The use of race in medical and health research has been at the center of many debates. In summarizes these debates, Daniel Howard (2002) notes that some researchers in health lack an understanding of the significance of race. Howard points out three unresolved issues that impede the progression of health research involving race. First, he notes that some researchers have an understanding of race only on the surface level. In other words, what they understand by the notion of race is only a difference in phenotypic characteristics, or skin color (LaVeist, 1994; Reed. 2003). Second, health research uses race broadly. Studies sometimes neglect the wide range of differences 
within racial groups, which can include such factors as gender, age, class, educational level or occupation status (Williams and Collins, 1995). Third, Howard states that some researchers have began to question the validity of the schematic racial categories used to classify individuals. These categories are based off of biological differences within humans, and most social scientists agree that race is more of social construct than a biological one (Howard, 2002; LaVeist, 2002; Reed, 2005; Root, 2003, Takeuchi and Gage, 2005).

This chapter will explore these debates in relation to the explanations given to explain the persisting level of racial inequalities in health. It will start with a discussion over the use of the term race or ethnicity in health research. This debate is tied closely to the third point given by Howard and is centered on the accuracy of race as a measure. The remainder of this chapter will explore the five models used in health research to explain racial disparities. Each model possesses distinguishing characteristics that aim to clarify the causes of racial disparities in health, and each can be employed alone or in combination with another model. The aim of this chapter is to elucidate the issues that have arisen when using race in health research and discuss the questions that have surfaced over the use of race and its value in explaining health inequalities.

\section{RACE OR ETHNICITY}

The use of race as a concept in health is a complicated and delicate matter. One of the key arguments surrounding the use of race in health research has been the debate on whether to use the word race or ethnicity (Agyemang, Bhopal and Bruijnzeels, 2005; Bradby, 1995; Dein, 2006; Comstock, Castillo, and Lindsay, 2004; Williams, 1997). 
Studies that have assessed the use of race or ethnicity in health research found that these terms are used interchangeably, have no standard definitions, and that many times researchers do not define how they have interpreted the terms for the purpose of their research (Comstock et al., 2004; Drevdahl, et al., 2006).

Race and ethnicity are terms that are used interchangeably in studies on race and health in the United States (Agyemang et al., 2004; Comstock et al., 2004). This practice could be based on the ambiguous use, and definition, of the terms within US agencies such as the U. S. Census Bureau and the Office of Management and Budget (OMB) (Comstock et al, 2004; Drevdahl et al., 2006; Takeuchi and Gage, 2003; Williams, 1997). The OMB is responsible for implementing the current guidelines for racial and ethnic groups, which are observed in all official demographic research within the United States. The OMG recognizes five racial groups: American Indian or Alaska Native; Asian; African American; Native Hawaiian or other Pacific Islander; and White. Hispanic or Latino is the only ethnic category recognized, and its definition encompassing all South or Central Americans and/or Spanish speaking cultures regardless of the race of that person (OMB, 1997). Therefore, even within the guidelines set by OMB the meanings of race and ethnicity are ambiguous and used interchangeably, which could be one of the reason the terms are used so loosely in the United States (Comstock, et al., 2004; Drevdahl et al., 2006).

Advocates for the use of the term ethnicity state that it is a more encompassing term and that it is a real term, in contrast to race, which is real. They argue that ethnicity is real because it pertains to shared common origins culture, language, religion, work, behavior, and knowledge passed from one generation to the next. This differs from the 
term race, which uses phenotypic variations between groups as its foundation (Agyemang et al, 2005; Arthur and Katkin, 2006; Bradby, 1995)? Recent studies in support of ethnicity over the concept of race have been conducted concerning the use of ethnic divisions within the African American population (Agyemang et al, 2005; Arthur and Katkin, 2006).. The ethnic categories within the African American population actually refer to people of the African descendent living in the United States that differ by birthplace and cultural differences. Meaning that a person of African descendent born and raised in the United States will have a different cultural background than an African descendent born person from the Caribbean, and these differences between the two populations can produces distinctive health outcomes (Arthur and Katkin, 2006; Bradby, 1995). Carlotta Arthur and Edward Katkin (2006) found that differences in cultural background could also produce psychosocial differences due to an individual's exposure to racism. Therefore, racism is also a contributor to negative health outcomes. However, it can be argued, that in the United States these differences are negated because generations beyond the first are not affected the same by cultural characteristics (Dein, 2006).

The effects of ethnicity become less important because every person of African descent is characterized as an African American, as each generation becomes more acculturated into American society. The presence cultural difference may still play a part in the construction of health, but like all other African Americans, the most damaging effects to health come from social conditions. Interactions within society construct specific social conditions, and racial discrimination heavily dictates these interactions for African Americans (Dein, 2006; Krieger, 1999; Williams, Neighbors, and Jackson, 2003). 
However, this does not mean that all individuals are affected the same by racism (Williams, 1997). Overall, all minorities groups suffer from a greater degree of inequity in health, but the health of each person varies according to both the illness or condition that plagues the individual and social factors that distinguish each individual in society (Krieger, 1999; Smedley, Stith, and Nelson, 2003; Williams, 1997; Winker, 2004).

The significance of racism is that it does not just affects any individual outside of the majority group. Therefore, even though ethnic variations can exist within racial groups, the wrath of racism will affects every individual of that group in some way. David Williams (1997) defends the use of the term race because he feels that if it is abandoned it will ignore, or deny, the conflict between racial groups in society over power and the stratification of society along lines of race. Terminating, or replacing, the use of race or racial categories minimizes the historical struggles of people of color who have been subjected to a lack of power and an ideological overtone of supremacy since the birth of the nation (Cooper, 2002; LaVeist, 2002; Smaje, 2000a, 2000b Williams, 1997). While the use of race can seem problematic within health research, it is an important factor to study because of its impact on society's makeup. Instead, of abandoning the term many researchers are now trying to figure out better ways to employ the term within their studies in order to better conceptualize its impact on the well-being.

\section{THE MODELS FOR STUDYING RACE IN HEALTH RESEARCH}

Investigators of health inequalities have developed several approaches to the study of race in health. Each approach portrays its own unique reason for the importance of race in health research. These models are used to theorize why inequalities have persisted 
and how inequity should be measured in an effort to improve the state of health of racial minorities. A summary of those models that have been consistently utilized will be explained in this section of the chapter in order to explain the racial differences in health outcomes. It will concentrate on five models of study: racial-genetic model, healthbehavior model, socioeconomic status model, psychosocial model, and structuralconstructivist model.

\section{Racial-Genetic Model}

The racial-genetic model states that groups vary according to the distribution of genetic variants, thus aligning these groups into the preset categories of race (Dressler, 1993; Dressler, Oths, and Gravlee, 2005; Griffith et al., 2006; Takeuchi and Gage, 2003). Many researchers within the social sciences have criticized this model because it supports the notion of race as a biological construct (Dressler, 1993; Dressler, et al., 2005 LaVeist, 2002; Smaje, 2000b; Tashiro, 2005; Williams, 1997). However, supporters of the model like, Burchard et al. (2003) declare that even though [racial categories] are not biological in nature, racial or ethnic groups do differ from each other genetically, which is biological in its implications.

Some of the main proponents of the racial-genetic model have been geneticists affiliated with the recently finished human genome project. The goal of genetic research in health is to identify specific genetic schemes that code for a variation of traits that can be important to the etiology of many disorders and diseases (Shields et al., 2005). These scientists work under the umbrella of one of the newest branches of genetics called genomics (Cooper, Kaufman, and Ward, 2003; Fine, Ibrahim, Thomas, 2005; Shields et 
al, 2005).

The Center for Disease Control (CDC), National Office of Public Health Genomics defines genomics as, "the study of all genes in a person, as well as interactions of those genes with each other and with that person's environment" (CDC, 2007). In relation to racial health disparities, genetic interaction between groups is usually measured by phenotypical traits that are then used as a proxy for genotypic testing for diseases (Fine et al, 2005). Researchers in genomics claim that by studying the genetic makeup of racial groups they are actually examining the geographical ancestry of an individual (Burchard et al, 2003).

In support of the racial-genetic model, studies have noted differences according to race in conditions such as hypertension, and diseases such as those that afflict the cardiovascular system and sickle cell anemia (Burchard et al, 2003; Phimister, 2003). To fight heart failure pharmacogenetics recently developed a new drug. Pharmacogenetics is a branch of pharmacology that looks at the relationship of genes and certain pharmaceutical drugs. The Food and Drug Administration (FDA) approved the pill, BiDil, in 2005, specifically for the use of persons who identify themselves as African Americans (Agyemang et al., 2005).

Those that contest the viewpoint of the racial-genetic model state the usefulness of the model is limited and that promoting the race as a biological construct reinforces racism and the continuing levels of inequity in society (Cooper et al., 2003; Dein, 2006; Reed, 2005; Root, 2003; Takeuchi and Gage, 2003). While the model can be helpful in uncovering the etiology of diseases and factors that influence the etiology of diseases, alone it does not fully explain the occurrence or distribution of these diseases throughout 
the population. Unequal quality of health care and the lack of access to health care caused by the adverse effects of socioeconomic factors attribute to the unequal mortality rates for certain types of cancer in African Americans (Root, 2003; Shields et al., 2005; Williams, 1997). While there is not many arguments that oppose the notion that genetic factors can affect health, these factors alone do not sufficiently explain the overwhelming amount of disparities in health by race.

\section{Health-Behavior Model}

The health-behavior model explains racial inequalities in health though lifestyle or behavior choices. Instead of focuses on genetic differences between races, it concentrates on factors that can be associated with culture such as diet, sexual behavior, smoking, alcohol consumption and physical activity (Dressler, 1993; Dressler et al., 2005; Griffith et al., 2006). In this model, certain behaviors are seen as detrimental to health and possibility of a health life rest on the termination, or at least reduction, of such behaviors (Dressler et al., 2005). While the health-behavior model delineates many important factors that contribute to health, it does have disadvantages.

There has not been a lot of evidence to support the idea that behavior alone can explain the level of inequity in health (Dressler, 1993; Dressler et al., 2005; Griffith et al., 2006). This point can be illustrated using smoking as an example. Statistically, there is only is only a little difference between the percentage of African Americans who smoke versus the percentage of Whites who smoke (Dressler et al., 2005; Shields et al., 2005). However, looking at the illnesses associated with smoking shows vast differences between the two groups. African Americans have higher rates of death for cancers 
affiliated with smoking such as the lungs, oral cavity and esophagus. However, behavior alone cannot explain these differences. Shields et al. (2005) state that one of the most important factors to evaluate when examining the risk from smoking are levels of SES. On average African Americans have a lower SES than whites, and individuals who are in the lower levels of SES are twice as likely to smoke (Shields et al., 2005).

One other reason that that health-behavior model can be disadvantages is because it can affirm the notion that the onset of an illness is the fault of the person because of the person choice to act in such a way; the person deserves the illness for his/her behavior (Dressler, 1993). Furthermore, it seems to support the notion that only cultural practices contribute to the disproportionate distribution of health disparities (Dein, 2006). This explanation has been used to elucidate the acquisition of sexually transmitted diseases, especially in the midst of the HIV pandemic (Vergehese, 1995).

Since the onset HIV, it has been associated with persons of certain lifestyles or culture, specifically homosexuals, persons addicted to drugs, and most recently people of African decent. The behaviors of those within these lifestyles, or cultures, are seen as unhealthy and because of their behavior, contracting the disease is their fault (Vergehese, 1995). Dein (2006) explains this process by using the term 'essentialism'. Essentialism means to ascribe specific qualities as being innate to a particular group.

Dein states, "essentialism can lead to stereotyping and racism...White as a category is never seen as problematic...[it] is seen as normal; and differences [from White] are seen as pathological" (71). Consequently, this can reinforce the misconceptions about racial groups pertaining to how people from that group act. Explanations like this can be hazardous to the fight against health inequalities because it 
takes the responsibility of improving the state health, and decreasing the level of inequality, off society and places it all on those that are affected by health disparities. This model does not take into account the social or political factors that influence a person's behavior of lifestyle, and this shortcoming inhibits it from fully explaining racial health disparities (Dressler, 1993).

\section{Socioeconomic Status Model}

The socioeconomic model argues that African Americans and other minorities are disproportionately represented in the lower levels of most socioeconomic factors (Dressler, 1993; Dressler et al., 2005; Griffith et al., 2006; Link and Phelan, 1995). Within the Untied States, socioeconomic status (SES) has been a determinant commonly employed by health researchers to help measure class status (Krieger, Williams, and Moss 1997; Pearl, Braverman, and Abrams, 2001; Williams and Collins, 1995). SES is one of the strongest predictors of health and intertwined with race SES becomes a valuable measurement for the study of racial health inequalities (Kreiger et al., 1997; Oliver and Muntaner, 2005; Williams and Collins, 1995).

In a study of infant birth weight and neighborhood SES, a relationship was found between race, neighborhood SES and a decline in the birth weight. In general, when controlling for race low birth weight was also observed in areas of low SES more frequently than areas of higher SES. Moreover, infants born to African Americans and Asians in neighborhoods with a low SES showed a higher average of low birth weight than their white counter parts, and within the white community neighborhood SES was not a factor in infant birth weight (Peal et al, 2001). This study demonstrated the 
importance of measuring SES in health research, but more importantly, it showed how influence SES alongside race could have an even more significant effect on health of racial minorities in the United States. However, like the previous models, SES alone cannot completely explain all racial disparities in health

SES is one of the most important factors to observe when study racial inequalities of health, but inequalities still do exist when SES levels are controlled (Cooper et al., 2005; Dressler, 1993; Dressler et al., 2005; Smedley, Stith, and Nelson, 2003; Williams, 1999; Williams and Collins, 1995, 2001). Many researchers have attributed this lingering difference in health to racism. Williams and Collins (2001) demonstrated that racism has detrimental effects on the development, implementation, and interpretation of policies and laws. In turn, these racist laws affect African Americans at a much higher right, which also constructs the unequal distribution of African Americans in lower SES levels.

Therefore, it is vital to study SES, but as a model, it does not provide a complete explanation of racial disparities. Instead, in order to start conceptualizing the effects of race, this model should be employed in conjunction with other explanations of racial disparities. One model that does use racism as an explanation of racial disparities is the psychosocial model.

\section{Psychosocial Model}

The psychosocial model attempts to explain the persisting degree of inequality present after controlling for SES. Unlike the other models, this model attempts to measure racism by examining relationships between perceived discrimination and levels 
of stress. Stress can affect African Americans in different ways than whites. The combined level effect of stress and racism harms the state of health. Moreover, these effects are compounded effects of low SES factors are considered. Research on racial health inequalities view stress as a product of racism measured by the people's perception of racial discrimination. The studies conducted on racial inequality in health correlated a higher level of stress to a lower level of well-being in areas of both mental and physical health (Clark et al., 1999; Williams et al., 2003).Stress from home, in the community, and at the workplace all served as mental factors that can lead physical manifestations of illness for individuals. Furthermore, these negative effects on health are be intensified by the effects of racism Clark, Anderson, Clark and Williams, 1999; Dressler et al., 2005; Griffith et al., 2006; Krieger, 1999; Williams et al., 2003).

Fowler-Brown and colleagues (2006) study found that African Americans perceive a greater level of racial obstruction in health care compared to whites within similar socioeconomic status.. Moreover, Saffron Karlson and James Nazroo (2004) study goes one-step further, explaining that the psychological fear of racism affects health negatively for non-white racial groups. Their study stated that the fear of racial discrimination, at institutional and individual levels, affect the psychological health of minority populations. Independent of SES the health of racial minority groups stress brought on by racism can alter the health minority populations (Clark et al., 1999; Fowler-Brown et al., 2006; Karlson and Nazroo, 2004; Williams et al., 2003).

One important limitation of the psychosocial model is that the model rests on the measurement of stress, which is not easily measured. The most common measurement of stress is the personal perceptions of individuals. While this does give a better idea of the 
role of racism and health, it can lead to methodological problems. It does not clearly elucidate how in certain groups discrimination can lead to a higher risk of diseases. In order to clarify this association with stress and racial health a better measurement of effects of stress and discrimination is needed (Williams, et al., 2003).

\section{Structural-Constructivist}

The last model is the structural-constructivist model. At the heart of the structuralconstructivist model is the premise that race is socially constructed. This model is, "based off of the social construction of race...emphasiz[ing] the intersection of social structures with the cultural construction of values, goals and aspirations as the causes of differences in morbidity and mortality" (Griffith et al., 2006: 476). Within this intersection of social structure and cultural construction are social, psychological and biological processes that affect the health of individuals. In contrast to the biological definition of race, the social construction of race is associated with a perceived hierarchical difference. Race is not a natural or neutral order but a product of lived experience shaped by historical process and contemporary social interactions (Dein, 2006; Dressler et al., 2005; Griffith et al., 2006; LaVeist, 2002; Mayberry, Mili, Ofili, 2000; Smaje, 2000b; Williams, 1997, 1999). Through the structural-constructivist model in order to understand the concept of race the radicalized meanings of other social factors such as, age, gender and class, must also be taken into account in order to comprehend the complexity of health inequalities (Dein, 2006; Krieger, 1999; LaVeist, 1994; Williams, 1997, 2000).

Similar to the concept of race, the variety of models demonstrate a lack of 
consensus on the measurement and use of race in health research. Each model has its strengths and weakness and each should not be thought of as autonomous examples. Most social scientists have adopted an approach similar to structural-constructionist and incorporate elements of several other models into there studies in an attempted to resolve the question of racial health inequalities (Griffith et al, 2006). An example would be the socio-cultural construct of race put forth by many opponents of the racial-genetic explanation. This view combines both the structural-constructionist model and the health behavior model and explains race as an admixture of ancestry, education, language, economic status and social factors (Fine et al., 2003).

One of the best representations of an amalgamated version of the five explanations for racial inequalities in health is the model presented by David Williams. Williams' (1997) model describes the liner progression of health starting with basic causes that affect health and ends with the variation of illnesses manifested within individuals. Racism is at the center of this model and was included as a basic cause of health. Both biology and geographic origins can affect racism, and it influences culture, economic structures and political and legal institutions. Basic causes lead to the social status stage, in which include social factors such as SES, gender, and age.

The next stage is surface causes. This stage characterized by elements of the psychosocial and health-behavior models, such as stress and behavior. Surface causes give rise to biological processes. In the linear progression of health, this stage affects biological functions. Biological functioning is associated with systems of the body such as the cardiovascular or endocrine. This path ends with the manifestation of illnesses in the human body. At this final stage, illnesses displayed in a person range from a high 
point of positive health to the most harmful health status of death.

Williams' model demonstrates the importance of studying race in relation to health and it supports the notion that effects of race are understood better, when the term is used as a concept in health research (Williams, 1997). These models provide a theoretical approach to measuring the role of race in health care. Recently the last model, and variants of it, has emerged as the most useful to health researchers (Dressler et al., 2005). However, in order to better clarify the complete significance of race newer, revised models will be needed that can better measure the impact of racism.

This chapter attempted to provide a better understanding of the explanations used to describe racial disparities in health. While these explanations give an understanding of why disparities exist and the importance of studying race in health, they do not sufficiently demonstrate how race should be studied in health research. A goal of this thesis is to help elucidate how race is study in health research and clarify the factors that are important to take into account when study race. The next chapter will explain the methodological approach that this thesis will apply in order to evaluate the use of race in health research. 


\section{CHAPTER IV \\ RESEARCH METHODOLOGY}

The 1985 study, Report of the Secretary's Task Force on Black and Minority Health by the Department of Human and Health Services (DHHS), is described by many researchers as one of the first attempts by any governmental health agency to investigate the serious degree of disparity in health between racial minority groups and the majority population or white population. This report fueled an upsurge of literature on the health status of racial groups in the United States and since its publication, there have been numerous studies examining the association between health inequity and racial status (Mayberry et al., 2000). Moreover, this surge in research over the past twenty years has ushered in a plethora of old, new and/or improved investigation methods and techniques; all aiming to better measure the dynamics that influence the level of health in the United States.

The current study is a continuation of the emergent research focused on examining the association between health inequity and racial status since the release of the Secretary's Task Force report. The study adopts a content analysis method to evaluate prior research conducted on access and quality of health care for African Americans between the years of 2000-2005. It is a qualitative inquiry of studies that examine racial disparities in the health care system, in general, as well as of more narrowly focused 
research on cancer, race and healthcare. Specifically, the study examines the treatment of the intersection between race and class in these studies to understand the extent to which the effect of social class and/or race causes health disparities.

This chapter discusses the use of content analysis as the method adopted in the study for collecting and analyzing the data. Under sampling and data procedures, it explains the rational for selecting the database and the research materials used for the analysis. A detailed description of the coding process, that was employed to systematically analyze the data and strategically present the findings, is provided in the section on data processing and analysis. The end of this chapter presents a brief description of the limitations of the study.

\section{CONTENT ANALYSIS}

A form of inquiry that has been useful in understanding the progression of research has been the use of extensive reviews of journal publications, or content analysis. Content analysis allows for a systematic study of various forms of communication, and it can be employed in either qualitative or quantitative studies. It is a branch of research that critically evaluates pre-existing data, and by definition, content analysis is the study of any form of recorded human communication including books, journals, websites forms of art, and written laws (Babbie, 2007; Mayring, 2000). An advantage of content analysis is that it allows researchers to evaluate a subject of study over a controlled span of time (Babbie, 2007). In the case of health, it allows the investigator to track the progression, or digression, of certain trends in health that play 
key roles in the formation of new, and the preservation of old, forms of disparities in health.

Qualitative content analysis is defined as "an approach of empirical, methodological controlled analysis of texts within their content of communication, following content analytical rules...[but] without the rash of quantification" (Mayring, 2000: 2). In comparison to quantitative content analysis, the results generated from a qualitative content analysis go beyond the standard counting of data and the subsequent categorization of results. Qualitative research is interpretive in nature (Creswell, 2003), and in use with content analysis it allows for a more holistic or macro-analytic view of social phenomenon (Babbie, 2007). Therefore, qualitative content analysis allows researchers to make inferences about way certain portions of text are included, and it allows for an interpretive conclusion as to what is meant by the use of certain phrases and words within the chosen medium. Many times this method uses a comparative approach to research, scrupulously drawing parallels between similar events and at the same time exposing the underlying differences of these events all in an effort to better grasp the importance of a specific phenomenon of study (Babbie, 2007; Mayring, 2000).

Content analysis starts, inductively, with examination of a particular form of communication and concludes with the researcher, in combination with some theoretical background, uncovering important relationships and patterns within the text. The researcher then utilizes the relationships and patterns that are derived from this analysis, during the formulation of categories, or coding process, which ultimate directs the analytic portion of qualitative content analysis research (Mayring, 2000). Researchers will then use these finding to make inferences about fundamental points, which they feel, 
should be taken into consideration when referring to a particular event (Babbie, 2007; Mayring, 2000).

\section{SAMPLING AND DATA PROCEDURES}

In order to search for relevant articles to analyze the study selected to use the United States National Library of Medicine's leading research database MEDLINE (Medical Literature Analysis and Retrieval System Online). MEDLINE covers close to sixty years of printed research and offers access to more than 5,000 biomedical and health related peer-reviewed journals. This includes journals from life and chemical sciences, as well as specialized areas relevant to this study such as, behavioral sciences, public health, health policy, and health education (NLM, 2007). A general search was conducted to retrieve articles concerning racial inequalities in health. Articles selected for use were limited to studies that examined aspects of access and quality of health care for African Americans. From these articles, keywords related to access to health care and quality of health care for African American's was formulated. These keywords include African Americans, Health Services Accessibility, Quality of Care, Barriers of Care, Racial Discrimination, and Health Inequalities. By using a combination of these keywords, a general listing of significant articles was populated.

\section{Definition of Terms}

In this thesis, access to heath, care and quality of heath care are presented as two separate determinants of health. However, it should be noted that the two are not mutually exclusive. The factors that limit access to health care are many times the influential factors that determine the quality of health care received. Therefore, although 
they can be studied separately, many times they actually work in a symbiotic relationship, each serving as a precursor for the results of the other (Howard, 2002; Smedley et al., 2003; Williams, 1997).

Access to health care can be characterized by such factors as availability, affordability, and accessibility of care (Howard, 2002). This would include whether or not the individuals studied have a primary care physician and if so, whether or not that physician is accessible relative to the location of the patient. Access to health care can also incorporate financial barriers that are whether or not the individuals can afford treatment or if they have insurance coverage (Mayberry et al., 2000).

Quality of care essentially pertains to the source of care. The source of care can be a primary physician, ambulatory services, local clinics, or emergency room service. Factors such as the physician-patient relationship, how often the physician sees the patient and the physician's attitude toward the patient are also considered measures for quality of care (Cooper et al., 2005; Cooper-Patrick et al., 1999). Important to understand for this study is how both access to care and quality of care affect the type of care received by patients and the role race plays in facilitating this care.

\section{Selection Criteria}

First, only articles published between the years of 2000-2005 in peer-reviewed journals were included in this study. This study begins in the year 2000, where Mayberry and colleagues, (2000) study ended. Their study looked at journal articles specific to access of care and race or ethnicity from the time the Secretary's Task Report was publish, in 1985 , to the year 1999 . The year 2000 was chosen as a starting point for this inquiry because it coincides with the publication of the DHHS Healthy People 2010 
report. One of the main goals professed in the Health People 2010 report is to eliminate all health disparities by the year 2010 (US DHHS, 2000). This thesis aims to help provide a limited understanding of the progression made toward this goal at its halfway point, 2005. This five-year selection span was also chosen because it covers the completion of the human genome project. The completion of this project serves as the starting point for the development of genomics, which has been very influential in the debate concerning the use of race in medical and science research.

\section{Organization of Selected Articles}

Articles selected had to have a clearly stated purpose statement that pertained to African American's access or quality of health. Studies that stated an aim of examining minority or racial groups in there purpose statement, or title, were included in the initial search, however these articles were discarded if African Americans were not one of the minority or racial group focused on in the study.

The articles retrieved from this process were then further divided into access or quality of health articles that gave an overview of racial health inequalities for African Americans, and articles that were specific to conditions that arise from certain forms of cancer for African Americans. The articles concerning racial health inequalities were not specific to any disease. These articles provide an analytical overview of race in health care and the implications of this concept for African Americans and other racial groups. Many of these articles were qualitative studies that relied on an extensive review of data. There were 27 articles on racial health inequalities, and 37 articles on race and cancer deemed most salient for this study. 
Articles specific to cancer were then used to observe a set of more narrowly focused research articles on the effects of race and health care. Articles on cancer were selected because cancer represents the second leading cause of death in the African American community and research in cancer makes up one of the largest sections of research in health and health care. It was chosen as a condition to study because it is one of the top three causes of death in the United States regardless of the racial group studied. Therefore, cancer's role in the health system is of central importance to all groups within the United States. However, African Americans suffer from the highest rate of mortality and morbidity from the disease (Byrd and Clayton, 2000; Jones, Hernandez-Valero, Esparza, and Wilson, 2001). The nature of this disease is always evolving and this characteristic has allowed for a rich collection of research relating to both the onset of progression of the diseases.

Cancer is a chronic health disease that covers a large range of locations throughout the human body, and African Americans have higher occurrences of cancer in nearly all of its manifestations in the human body (Jones et al., 2001). A general understanding of the level of inequality in the distribution of cancer for African Americans will be inferred from this analysis. However, it is not the goal of this study to give a description of the effects of this condition within segments of the African American community, but instead use the research conducted on the effects of this disease to understand the use of race as a concept of study in health research. Unlike the articles general articles pertaining to race and health inequalities, these studies were limited to articles that presented original data, meaning that articles labeled as reviews, editorials, or comments were excluded. 


\section{Data Processing and Analysis}

In order to code the relevant material, articles were first read in their entirety and information was recorded in a table using the following criteria:

(a) Article; author name and year article was published,

(b) Research Design; quantitative or qualitative approach.

(c) Sample Population; gives demographic information concerning the sample used in the study, such as gender, age, race.

(d) Use of Race; coded as either a variable or a concept. (Using race as a concept entailed an understanding of the stringent factors within society that can affect race, including racism. It also means that these articles attempted to measure and analyze the relationship between race and social factors, such as social measures of class.)

(e) The Theoretical Model: used to Explain Racial Health Disparities; racial genetic model (RG); health behavioral model (HB); Socioeconomic Status model (SES); psychosocial model, (PS); or structural-constructivist model, (SC).

(f) Analytic Measure of Social Class; (e.g. income, education level, poverty status, etc.)

(g) Race/Class Intersection; yes, meaning a race/class intersection was observed, or no, meaning no race/class intersection was observed. If yes was coded for a race/class intersection the article had to use a measure of class in their analysis of racial disparities. Meaning, that if a measure for 
social class was used for demographic information only, and not employed in the analysis of the study, there was no race/class intersection.

(h) Focus of Analysis; causes of racial health disparities or outcomes of health disparities.

(i) Primary Causal Factors; key determinant(s) identified as the cause of racial disparities in health.

\section{Limitations}

Although MEDLINE is one of, if not the most, extensive collection of health related, journals it does not provide access to every health or science related journal. There is the possibility that a small portion of published articles about health care and African Americans are will not be available in the MEDLINE database. At the same time, there is also the possibility that certain articles, that would have been included in this study, are not published in health or science related journals, thus meaning they would be unavailable through this database. 


\section{CHAPTER V}

\section{FINDINGS}

This chapter is a discussion of the literature on race and health inequalities, and race and cancer research. The chapter begins with a brief explanation of race as a concept in health research, and then presents the findings obtained from the analysis of the selected literature. An explanation of race as a concept is presented in order to grasp the importance of studying race in health research and to delineate some of the factors associated with the conceptualization of race. For this study, this understanding of race serves as the focus of the analysis of the health literature. Following this section are discussions on race and health inequalities in general (Tables 1 and 2), and race and cancer research (Tables 3,4 and 5). Each table is divided into two sections in order to display the results from the data collected. The first section provides an explanation of the research design, sample population, the focus of analysis, and analytic measure of social class, used in each of the selected articles. The second section presents the use of race, observed race/class intersection, the model employed when explaining racial inequalities and the primary causal factors identified in the selected articles.

\section{CONCEPTUALIZING RACE IN HEALTH RESEARCH}

Historically, racial categories in the United States have been based on simple phenotypical differences that a person displays, namely skin color. However, challenge 
by social scientists to this biological interpretation of race have led to an understanding of race as a social construct. This effort by researchers was an attempt to understand better the effects of race. Thomas LaVeist (1994) however, notes that race still needs to be conceptualized better if researchers are to understand all the factors that lead to racial disparities in health. LaVeist (1994) argues that health research concerning racial inequalities merely uses race as a variable. Many times, when using race as a variable, it is believed to be objective, or neutral, and it is assumed that the effects of race are easily measured in contrast to other racial groups (Winant, 1994). Essentially, using race as a variable yields results that support the notion of skin color as the main proxy for differences observed between groups. Studies that utilize race as variable rarely go beyond this simplistic explanation or race. Thus, these studies often overlook both the historical and contemporary consequences of race (Clark et al., 1999; LaVeist, 1994; Williams, 1997; 1999).

To conceptualize race, studies have to explore race in conjunction with other social factors and to place the effects of race within proper historical and contemporary contexts (Winant, 1994; LaVeist, 1994; Williams, 1997). Throughout history, African Americans have always been subjected to a greater amount of discrimination. Thus, due to racism African Americans have a greater probability of poverty compared to their white counter parts. Racism has been, and continues to be, a key contributor to structure of society and to the unequal state of health for African Americans (Williams, 1997; Williams and Collins, 1995).

In order to conceptualize race properly, researchers should seek to understand both, between group differences and differences within the diverse segments of the 
African American community (LaVeist, 1994; Oliver and Muntaner, 2005; Williams and Collins, 1995). African Americans are a dynamic group that cannot be studied as a single uniform group if the affects of race are to be properly assessed. African Americans come from disparate geographical locations across the country, belong to different social classes, and have various cultural beliefs, which all contribute to a very diverse admixture of cultural and social factors that determine both life chances and health outcomes (LaVeist, 1994; Williams, 1997).

One of the central, yet most complex, factors associated with race is social class. Social class refers to an individuals location within society based upon structured economic categories (Krieger et al., 1999). Social class measures such as income, education, or poverty directly effect health outcomes in the United States, and health care in the United States is influenced directly by the ability to pay, either for health care or healthy living conditions (Bury, 2005; Krieger et al., 1999; Lahelma, 2001; Scott, 2007; Smedley et al., 2003; Williams and Collins, 1995). Racism at the structural level affects the number of African Americans that are in the lower levels of social class measures. Therefore, social class is important to the study of racial health inequalities due to the negative impact of racism (Krieger et al., 1999; Williams, 1997; Williams and Collins, 1995).

\section{STUDY DESCRIPTION}

The racial makeup of the sample population is important. It gives an understanding how the studies perceive the diverse outcomes of health, by comparing levels of inequality in health either between racial groups or within a racial group. When 
investigating racial disparities in health for African Americans it is important to know the comparison group, which will determine if the study explores within group differences or Black-White differences. In order to gain a full understanding of the effects of race, a within group comparison is needed. However, in both of these sets of data a greater percentage of studies focused their analysis on a comparison of health outcomes between African Americans and Whites. These findings suggest that there is a lack of intra-group comparisons in studies of race and health. However, the other 14 studies, 7 in each data set, were significant for this thesis because they attempted to look at the effects of race within group, or intra-group.

Differences within a racial group, such as social class measures, can produce a diverse number of effects that influence health outcomes for that group. Eleven of the fourteen studies that did use an intra-group comparison conceptualized race by evaluating the effects of race using certain measures for social class. These studies examined the effects of class within race. This offers greater degree of comprehension about true affects of race within the African American community, by isolating the social factors within the African American community that contribute to adverse effects of health. An intra-group sample is not a requirement for a study in order for it to conceptualized race, but it does provide the greatest amount information about the effects of race by separating out the social factors that yield different effects of health within the group.

The focus of analysis for each of the articles is coded as either causes or outcomes. Focusing on outcomes of racial disparities in health usually discloses only the degree of inequity either between racial groups or within racial groups. However, by focusing on the causes of inequalities in health researchers are compelled to elucidate 
many of the factors that are essential to the conceptualization of race. Studies that focus on the causes of racial disparities reveal the associations between factors such as education level, employment status, or racism, and race. Articles that focused on the causes of racial health disparities in general accounted 11 of the 20 articles for the data on race and health inequalities (Tables 1 and 2; Column 3). Six articles looked at both the causes and outcomes of racial disparities in health. Therefore, the majority of the articles, 17 in all, attempted to address the causes of racial disparities.

In the data set on race and cancer, there was nearly an equal distribution of articles that focused on causes, 18 articles, or outcomes, 19 articles (Tables 3, 4, and 5; Column 2). However, when assessing the use of race in these articles a greater percentage of studies that used race as a concept focused on the causes of racial disparities, 12 of the 18 articles. In contrast, 14 of the 19 articles, that focused on the outcomes of racial disparities used race as a variable. Therefore, most of the articles that used race as a concept focused on the causes of racial disparities and a greater portion of the articles that used race as variable focused on the outcomes of racial disparities.

This finding is significant because it supports the notion that conceptualizing race in health entails an understanding of the factors that influence disparities by race. The studies that did focus of the causes of racial disparities concentrated their studies on the determinants that modify health outcomes. Furthermore, studies that focus on the causes of health inequalities have an advantage over those studies that look at outcomes. These studies based on the causes of health inequalities also help understand why adverse outcomes in health are present. Therefore, these studies better conceptualized why race is 
so important to the study of health, and why racial differences in certain health outcomes are present.

\section{RACE AND CLASS ANALYSIS}

This study attempted to comprehend the affects of race by understanding its relationship with class. Each article was coded either as concept or as variable depending on the use, and understanding, of race in the analysis of the study. Articles that did comprehend the effects of race within their study were coded as a concept in Column, 5 of the data on race and health inequalities (Tables 1 and 2), and Column 4 in the data on race and cancer (Tables 3, 4, and 5). The first data set displayed a significant amount more of articles that used race as a concept. There were 15 articles (75\%), which used race as a concept throughout the analysis in the general articles on race and health inequalities, and 17 articles (43\%), in the data set on race and cancer. All 32 of these articles used a measure of social class and each article had a race/class intersection. This finding suggests that for race to be conceptualized within an article the article used some measure of social class, and it analyzed the effects of that measure in relation to race. This also implies that the presence of a race/class intersection is correlated directly with the use of race as a concept within an article.

\section{Analytic Measure for Social Class}

Measurements for social class included education level, income, poverty rates, and employment status. Educational level and income were the most commonly used measures for social class in both the data on race and health inequalities (Tables 1 and 2; Column 4), and race and cancer (Tables 3, 4 and 5; Column 3). These findings do show 
that the majority of articles examined in this study attempted to obtain some type of measure of social class for their analysis. However, there is no observed consistency in how social class is measured.

It can be difficult, if not impossible, to evaluate accurately the effects of race if a wide range of studies use different measures of social class. For example, studies that use income to measure of social class can be rendered non-comparable with studies that prefer to use a different measure of social class, such as education attainment, to evaluate the affects of race. Each unique measure of social class will produce a different meaning, and importance, of the role of race on health. Therefore, comparing the results of two studies on race and health that differ in social class measurement can yield a misguided, and inaccurate, conclusion about nature of race and its affect on health.

\section{Race/Class Intersection}

The intersection between race and class is one of the focal points of this study. If this intersection is present in the reviewed studies, the study attempted to conceptualize the effects of race, and they comprehended the effects of social class on race. The results from Tables 1 and 2, Column 6, of the general articles on race and health inequalities, show that the race/class interaction was observed only in the 15 articles that used race as a concept. Likewise, in the data set on race and cancer, 17 articles displayed a race/class intersection (Tables 3, 4 and 5; Column 5). These 17 articles were also the only articles within this data set to use race as a concept and employ some measurement of social class within their analysis.

This finding supports the notion that social factors, such as educational level or income, are needed in order to conceptualize the effects of race, and that the use of these 
factors should be used as an analysis tool within the articles and not just as a demographic variable. The intersection between race and class symbolizes an understanding of the use of race in as a concept and the importance of delineating the affects class has on race, or within a racial group.

\section{Explanation of Racial Disparities}

Displayed in Tables 1 and 2; Column 7 are the explanations given by each study as to the reason a disparity in health exist. The model used most frequently to explain racial disparities, regardless if race was used as concept or variable, was the structuralconstructivist model (SC). The SC model was 19 times in the data on race and health inequalities (Tables 1 and 2; Column 7), and 18 times in the literature on race and cancer (Tables 3, 4, and 5; Column 6). The frequent use of the structural-constructivist model suggests that most researchers defined race as a social construct, and not as a biological factor. However, this does not give any understanding as to the use of race as a concept or variable in the study. The only pattern observed between the use of race and the models to explain racial disparities was for the psychosocial model.

The model used most frequently in the literature on race and health inequalities was the psychosocial model. In the literature on race and cancer, this model was used once. The psychosocial model seeks to explain the relationship between stress and health. This model describes stress as product of racism. The psychosocial model was always coupled with the structural-constructivist model, and each time it was employed within a study race was used as concept. This result implies that when the psychosocial model is employed within a study race has been used as concept. It also suggests that an 
understanding of the causes that can contribute to a rise in the level of stress due to racism helps identify the characteristics that are necessary to conceptualize race.

\section{Primary Causal Factors}

The measurement of primary causal factors refers to the studies principal finding as to the cause of racial disparities. Racism was the most prevalent causal factor observed in this data. Fourteen of the 20 articles used in this sample concluded that the primary causal factor behind discrimination in health care for African Americans was racism. Eleven of these 14 responses were from articles that conceptualized race. This result indicates that greater acknowledgement of the role of racism. Articles that used racism as a primary causal factor and used race as a concept in the study showed a greater understanding of racism. In order to use race as a concept the article must also

The literature on cancer and race provided a more diverse set of explanations for primary causal factor. There were 12 different responses used as primary causal factors for this set of data. Education and changes in screening were the two responses detected in most studies that conceptualized race. Screening includes both improvement of screening procedures and a greater number of African Americans utilizing screening to detect cancer earlier in life. The primary causal force for studies that did not conceptualize race revealed an array of response. However, unlike the studies that did conceptualize race, these studies only had one response for education as a primary casual force. In addition, there were more responses for healthy behavior for these studies than for the studies that use race as concept.

In both of the sets of literature, racism, education, and screening procedures were the primary causal factors used most often in the articles that used race as a concept. 
However, this finding does not imply that that only articles using these three factors used race as a concept.

There was no clear pattern observed in for primary causal factors and the use of race as a concept in the literature. Meaning that the factors identified as the source of causation by the article have no affiliation with how the article understood the concept of race.

\section{Summery of Findings}

Overall, the findings from this thesis revealed that a lower percentage of articles on race and cancer conceptualized race in their study. However, by using both the data on race and cancer and the data on race and inequalities certain patterns pertaining to the conceptualized of race can be established. Articles that conceptualized race tended to focus of the causes of racial disparities instead of the outcomes. The models used to explain racial disparities in health tended to be either structural-constructivist or psychosocial, and the psychosocial model used only in the articles that conceptualized race. Finally, all of the articles that conceptualized race used some measure of social class and race/class intersection was observed for each article. This data revealed that an important link is present between the use of race as a concept and the presences of race/class intersection. Therefore, understanding race as a concept in health means to understand the effects that social class factors have on race, and to use this understanding to analyze racial health disparities. 


\section{CHAPTER VI \\ CONCLUSION}

This thesis set out to evaluate peer-reviewed journal articles that pertain to race in order to get a greater understanding of use of race in health research. Particularly, the goal of this study was to evaluate race in health research to help determine whether it is being used as simple variable or if researchers have attempted to conceptualize race in their studies. This study found that $75 \%$ of the articles pertaining to general health inequalities and race attempted to conceptualize race. However, only $43 \%$ of the articles that were limited to cancer used race as a concept. Therefore, this study supports the notion that race is being conceptualized often in the articles for general health inequalities, but the articles on race and cancer show that there is still a significant amount of studies that use race as a variable in research.

One explanation of these differences could be due to the fact that the majority of authors in the first data set are trained as social scientist. Social scientists tend to treat health conditions different from medical scientists and physicians. This is the distinction made between illnesses and diseases. Defining a health conditions as an illness takes into account the effects of social influences (Weitz, 2004). In contrast, a disease is primarily treated as a biological, or natural, manifestation of a pathogen within the human.

Therefore, differences in the conceptualization of race could be a result of the treatment 
of health conditions by researchers. If health conditions are only seen as a biological function, social conditions of race would be overlooked.

Furthermore, social scientists and researchers who have been trained in social science, serve as some of the leading advocates for the use of race as a concept in health research (LaVeist, 1994). Studies have already shown that for studies on health there has been an effort to collaborate more between different areas of social sciences, such as medical sociology and medical anthropology (Good and Good, 2000). This study supports the suggestion that these social scientist have, at least, begin to work with members of medical science fields. In contrast, in articles about cancer it is more common for an expert on cancer or a physician treating the disease to compose the article. This is not to say that physicians are unable to conceptualize race in their work, but instead this suggests that there are two different understandings of the consequences of race by social scientists and research physicians.

There were also a greater number of studies in the second data set pertaining to cancer that only concentrated on the outcomes of health between racial groups. The outcomes of health conditions are also connected to the view of treatment of health conditions as an illness or disease. Since diseases are seen as biological, causation of these ailments would not include social determinants such as race. However, in studies that due concentrate on the causes of health differentials, there is an effort to understand the effects of social conditions in health. In order to conceptualize race the consequences of race within society must be placed in it is proper context and accurately evaluated. Meaning, causes of racial inequalities in health must be examining along with the outcomes of health inequalities (Clark et al., 1999; Williams, 1997; 1999). This thesis 
suggests that more collaboration both the studies by social scientist and medical scientist and physicians are needed in order to holistically understand health and the affects of race.

One of these units of observation evaluated in this study was how social class is treated to help elucidate the affects of race. Social class is considered one of the focal causes of disparities in health care regardless of race. In most of these articles that were reviewed, social class was taken into account, but the measurements used for class varied from study to study. An accurate evaluation of the effects of race cannot be achieved if the measurements used for social class are not consistent. Meaning, a study that evaluates employment status is not comparable with a study that elevates household income.

Another concern pertaining to the conceptualization of race is the comparison between groups versus the comparison within groups. While comparing the level of disparity between races is important, conceptualizing race calls for both comparing between groups and comparing levels of disparity within groups (LaVeist, 1994; Oliver and Muntaner, 2005; Williams and Collins, 1995). Two of the articles reviewed (Jackson, 2005 and Williams, 2005) in this study also pointed out that it is important to start examining the health of middle class African Americans. Racism affects African Americans at all levels of social class in society and the factors that contribute to the state of health in the middle class can differ from those in the lower classes. Most studies in this sample did not take into account middle class. Instead, the majority articles in this thesis focused on African Americans with lower class. Even those studies that did 
controlled for an intragroup sample of African American neglected to evaluate the health of African Americans outside of the lower social class levels.

This study suggests that there is still no consensus on the conceptualization of race in health care research pertaining to specific diseases or illnesses. While the overwhelming number of articles on general health inequalities and race used race as a concept, less than half of the articles on cancer conceptualized race. Furthermore, using social class in research as measure can vary between studies. This implies that comparisons made between such studies could yield inaccurate conclusions, thus limiting the use of social class when evaluating racial health disparities.

Further studies are required to understand racial disparities and health. Cancer studies need further evaluation because of the nature of the disease. Cancer is seen at greater quantities in older adults and many of these studies on cancer controlled for this variable. In order to get a greater understanding of other age groups, other diseases that are less constrained by age should be evaluated. More studies are also needed to investigate the added effects of gender, which are as important as the effects race and class. Sandra Taylor (2001) notes that African American women have their own set of health problems that that go beyond the consequences of race and class. Gender plays a very important role in the conceptualization of race as well, and future studies should aggressively seek to elucidate these added effects in order to fully understand the role of race in health care research. 


\section{REFERENCES}

Agyemang, C., Bhopal, R., and Bruijnzeels, M. (2005) "Negro, Black, Black African, African Caribbean, African American or what? Labeling African Origin Populations in the Health Arena in the $21^{\text {st }}$ Century" Journal of Epidemiology Community Health 59: 1014-18.

Anderson, K. O., Richman, S. P., Palos, G., Valero, V., Mendoza, T. R., Gning, I., Cleeland, C. S. (2002). "Cancer Pain Management among Underserved Minority Outpatients: Perceived Needs to Optimal Control" Cancer 94(8): 2295-2304.

Armstrong, D. (1995). "The Rise of Surveillance Medicine" Sociology of Health \& Illness, 17(3): 393-404.

Armstrong J. and Bos, E (1992) "The Demographic, Economic, and Social Impact of AIDS" in J. M. Mann, D. J. M. Tarantola and T. W. Netter (eds). AIDS in the World: The Global AIDS Policy Coalition Cambridge and London: Harvard University Press.

Arthur, C. M. and Katkin, E. S. (2006) "Making a Case for the Examination of Ethnicity of Blacks in United States Health Research" Journal of Health Care for the Poor and Underserved 17: 25-36.

Ashley, D. and Orenstein, D. M. (2001) Sociological Theory: Classical Statements $5^{\text {th }}$ Ed. Needham Heights, MA: Allyn and Bacon.

Ashton, C. M., Haidet, P., Paterniti, D. A., Collins, T. C., Gordon, H. S., O'Malley, K., Petersen, L. A., Sharf, B. F., Suarez-Almazor, M. E., Wray, N. P., and Street, R. L. (2003). "Racial and Ethnic Disparities in the Use of Health Services: Bias, Preferences, or Poor Communication?" Journal of General Internal Medicine 18: $146-52$.

Babbie, E. (2007). The Practice of Social Research $11^{\text {th }}$ Ed. Belmont, CA: Thomson and Wadsworth. 
Baldwin, L., Dobie, S. A., Billingsley, K., Cai, Y., Wright, G. E., Dominitz, J. A., Barlow, W., Warren, J. L., and Taplin, S. H. (2005). "Explaining Black-White Differences in Receipt of Recommended Colon Cancer Treatment" JNCI Journal of the National Cancer Institute 97(16): 1211-1220

Balsa, A. I. And McGuire, T. G. (2003). "Prejudice, Clinical Uncertainty and Stereotyping as Sources of Health Disparities" Journal of Health Economics 22: 89-116.

Becker, H. S., Greer, B., Hughes, E. and Strauss, A. (1961). Boys in White: Student Culture in Medal School. Chicago, IL: University of Chicago Press.

Bibb, S. G. (2001). "The Relationship Between Access and Stage at Diagnosis of Breast Cancer in African American and Caucasian Women" Oncology Nursing Forum 28(4): $711-9$.

Bird, C. E., Conrad, P, and Fremont, A. M. (2000). "Medical Sociology at the Millennium" in C. E. Bird, P. Conrad, and A. M. Fremont (eds). Handbook of Medical Sociology ( $5^{\text {th }}$ Ed.) Upper Saddle River, NJ: Prentice Hall.

Blankenship, K. M., Smoyer, A. B., Bray S. J., and Mattocks, K. (2005) "Black-White Disparities in HIV/AIDS: The Role f Drug Policy and he Corrections System" Journal of Health Care for the Poor and Underserved 16: 140-65.

Blumer, H. (2003) [1962]. "Society as Symbolic Interaction" in P. Kivisto (ed.) Social Theory: Roots and Branches $2^{\text {nd }} E d$. Los Angeles, CA: Roxbury Publishing Company.

Boulware, L. E., Cooper, L. A., Ratner, L. E., LaVeist, T. A. and Powe, N. R. (2003). "Race and Trust in the Health Care System" Public Health Reports 118: 358-65.

Brooks, S. E., Chen, T. T., Ghosh, A., Mullins, C.D., Gardner, J. F., and Baquet, C. R. (2000). "Cervical Cancer Outcomes Analysis: Impact of Age, Race, and Comorbid Illness on Hospitalizations for Invasive Carcinoma of the Cervix" Gynecologic Oncology 79: 107-15.

Bradby, H. (1995) "Ethnicity: Not a Black and White Issue: A Research Note" Sociology of Health and Illness 17(3): 405-17.

Braithwaite, R. and Taylor, S. Eds. (2001) Health Issues in the Black Community $2^{\text {nd }}$ Ed. San Francisco, CA: Jossey-Boss. 
Brown, E. R., Ojeda, V. D., Wyn, R. and Levan, R. (2000). "Racial and Ethnic Disparities in Access to Health Insurance and Health Care" UCLA Center for Health Policy Research and The Henry J. Kaiser Family Foundation p. 5-12, 3142.

Bury, M. R. (1986). "Social constructionist and the development of medical sociology" Sociology of Health and Illness 8: 137-169.

Bury, M. R. (1998). "Postmodernity and Health" in F. Scambler and P. Higgs (eds.) Modernity, Medicine and Health: Medical Sociology Towards 2000. London: Routledge, 1-28.

Bury, M. R. (2000). Health, Ageing, and the Lifecourse. in S. J. Williams, J. Gabe, and M. Calnan (eds.) in Health, Medicine and Society: Key Theories, Future Agendas. London and New York: Routledge.

Bury, M. R. (2005). Health and Illness. Cambridge: Polity

Byrd, W. M and Clayton, L. A. (2000a). An American Health Dilemma: Vol. I, A Medical History of African Americans and the Problem of Race, Beginnings to 1900. New York: Routledge.

Byrd, W. M and Clayton, L. A. (2000b). An American Health Dilemma: Vol. II, Race Medicine, and Health Care in the United States 1900-2000. New York: Routledge.

Byrd, W. M. and Clayton, L. A. (2003). "Racial and Ethnic Disparities in Healthcare: A Background and History" in B. D. Smedley, A. Y. Stith, and A. R. Nelson (eds). Unequal Treatment: Confronting Racial and Ethnic Disparities in Health. Washington, DC: National Academies Press.

Center for Disease Control (CDC). (2007) "Frequently Asked Questions" CDC National Office of Public Health Genomics [online]. $<$ http://www.cdc.gov/genomics/faq/htm> Accessed February 26, 2007.

Clark, R., Anderson, N. B., Clark, V. R., and Williams, D. R. (1999). “A Biopsychosocial Model" American Psychologist 54(10): 805-16.

Cockerham, W. C. (1988). "Medical Sociology", in N. J. Smelser (ed). Handbook of Sociology. Newbury Park: Sage.

Cockerham, W. C. (2001). "Medical Sociology and Sociological Theory" in W. C. Cockerham (ed). The Blackwell Companion to Medical Sociology. Malden, MA: Blackwell Publishers.

Coe, R. M. (1970). Sociology of Medicine. New York: McGraw-Hill. 
Comstock, R. D., Castillo, E. M., and Lindsay, S. P. (2004) "Four-Year Review of the Use of Race and Ethnicity in Epidemiologic and Public Health Research" American Journal of Epidemiology 159: 611-9.

Conrad, P. and Schneider, J. W. (1980). Deviance and Medicalization: From Badness to Sickness. St. Louis: C. V. Mosby Company.

Conrad, P. (1997). "Parallel Play in Medical Sociology and Medical Anthropology" The American Sociologist 28: 90-100.

Cooper, G. S. and Koroukian, S. M. (2004) "Racial Disparities in the Use of and Indications for Colorectal Procedures in Medicare Beneficiaries" Cancer 100(2): 418-24.

Cooper, L. A., Beach, M. C., Johnson, R. L., and Inui, T. S. (2005) "Delving Below the Surface: Understanding How Race and Ethnicity Influence Relationships in Health Care" Journal of General Internal Medicine 21(s1): S21-27.

Cooper, L. A. and Roter, D. L. (2003) "Patient-Provider Communication: The Effect of Race and Ethnicity on Process and Outcomes of Healthcare" in B. D. Smedley, A. Y. Stith, and A. R. Nelson (eds). Unequal Treatment: Confronting Racial and Ethnic Disparities in Health. Washington, DC: National Academies Press.

Cooper, R. (2002). "A Note on the Biologic Concept of Race and Its Application in Epidemiologic Research" in T. A. LaVeist (ed). Race, Ethnicity, and Health: A Public Health Reader San Francisco, CA: Jossy-Bass.

Cooper, R., Kaufman, J. S. and Ward, R. (2003). "Race and Genomics" New England Journal of Medicine 348(12): 1166-70.

Cooper-Patrick, L. Gallo, J. J., Gonzales, J. J., Vu, H. T., Powe, N. R., Nelson, C., and Ford, D. E. (1999). “ Race, Gender, and Partnership in the Patient-Physician Relationship" Journal of the American Medical Association 282(6): 583-9.

Copeland, V. C. (2005). “African Americans: Disparities in Health Care Access and Utilization" Health \& Social Work 30(3): 265-70.

Creswell, J. W. (2003). Research Design: Qualitative, Quantitative, and Mixed Methods Approaches ( $2^{\text {nd }}$ ed.). Thousand Oaks: Sage.

Davis, C., Emerson, J. S., Husaini, B. A., (2005). "Breast Cancer Screening Among African American Women: Adherence to Current Recommendations" Journal of Health Care for the Poor and Underserved 16: 308-14. 
Dein, S. (2006). "Race, Culture and Ethnicity In Minority Research: A Critical

Discussion" Journal of Cultural Diversity 13(2): 68-75.

Drevdahl, D. J., Philips, D. A., and Taylor, J. Y. (2006). "Uncontested Categories: the use of Race and Ethnicity variables in Nursing Research" Nursing Inquiry 13(1): 5263.

Dressler, W. W. (1993). "Health in the African American Community: Accounting for Health Inequalities" Medical Anthropology Quarterly 7: 325-45.

Dressler, W. W., Oths, K. S. and Gravlee, C. C. (2005). "Race and Ethnicity in Public Health Research: Models to Explain Health Disparities" Annual Review of Anthropology 34: 231-52.

Durkheim, E. (1951) Suicide, a study in sociology: translated by John A. Spaulding and George Simpson. New York: Free Press.

Farley, J. H., Hines, J. F., Taylor, R. R., Carlson, J. W., Parker, M. F., Kost, E. R., Rogers, S. J., Harrison, T. A., Macri, C. I., and Parham, G. P. (2001). "Equal Care Ensures Equal Survival for African American Women with Cervical Carcinoma" Cancer 91(4): 869-73.

Field, T. S., Buist, D. S. M., Doubeni, C., Enger, S., Fouzyzi, H., Hart, G., Korner, E. J., Lamerato, L., Bachman, D. J., Ellis, J., Herrinton, L., Hornbrook, M. C., Krajenta, R., Liu, L., Yao, J. (2005). "Disparities and Survival Among Breast Cancer Patients" Journal of the National Cancer Institute Monographs 35: 88-95

Fine, M. J., Ibrahim, S. A., and Thomas, S. B., (2005). "The Role of Race and Genetics in Health Disparities Research" American Journal of Public Health 95(12): 2125-8.

Freedland, S. J., Sutter M. E., Naitoh, J., Dorey, F., Csathy, G. S., and Aronson, W. J. (2000) "Clinical Characteristics in Black and White Men with Prostate Cancer in an Equal Access Medical Center" Urology 55(3): 387-90.

Freeman, S. and Herron, J. C. (2001). Evolutionary Analysis $2^{\text {nd }}$ Ed. Upper Saddle River, NJ: Prentice Hall.

Foote, M. (2003). "Racial Disparities in Cancer Incidence and Mortality: Wisconsin and United States, 1996-2000" Wisconsin Medical Journal 102(5): 27-35.

Foucault, M. (1973). The Birth of the Clinic: An Archeology of Medical Perception: Translated by A. M. Sheridan Smith. New York: Pantheon Books. 
Fowler-Brown, A., Ashkin, E., Corbie-Smith, G., Thaker, S., Pathman., D. E. (2006). "Perceptions of Racial Barriers to Health Care in the Rural South" Journal of Health Care for the Poor and Underserved 17: 86-100.

Fox, R. C. (1985). "Reflections and Opportunities in the Sociology of Medicine" Journal of Health and Social Behavior, 26(1): 6-14.

Geronimus, A. T., (2000). "To Mitigate, Resist, or Undo: Addressing Structural Influences on the Health of Urban Populations" American Journal of Public Health 90(6): 867-72.

Goffman, E. (2003) "Performances" in P. Kivisto (ed). Social Theory: Roots and Branches $2^{\text {nd }} E d$. Los Angeles: Roxbury Publishing Company

Good, M. D. and Good, B. (2000) “'Parallel Sisters': Medical Anthropology and Medical Sociology" in C. E. Bird, P. Conrad, and A. M. Fremont (eds). Handbook of Medical Sociology $\left(5^{\text {th }}\right.$ Ed.) Upper Saddle River, NJ: Prentice Hall.

Govindarajan, R. Shah, R. V., Erkman, L. G., Hutchins, L, F. (2003). "Racial Differences in the Outcome of Patients with Colorectal Carcinoma" Cancer 97(2): 493-8.

Green, P. M. and Kelly, B. A. (2004). "Colorectal Cancer Knowledge, Perceptions, and Behaviors in African Americans" Cancer Nursing 27(3): 206-15.

Greene, A. L., Torio, C. M., Klassen, A. C. (2005) "Measuring Sustained Mammography Use by Urban African American Women" Journal of Community Health 30(4): 235-51.

Griffith, D. M., Moy, E., Reischl, T. M., and Dayton, E. (2006). “National Data for Monitoring and Evaluating Racial and Ethnic Health Inequalities: Where Do We Go From Here?" Health Education \& Behavior 33(4): 470-87.

Gwyn, K., Bondy, M. L., Cohen, D. S., Lund, M., Liff, J. M., Brinton, L. A., Eley, J. E., Coates, R. J. (2004). "Racial Differences in Diagnosis, Treatment, and Clinical Delays in Population-Based Study of Patients with Newly Diagnosed Breast Carcinoma" Cancer 100(8): 1595-1604.

Halabi, S., Small, E. J., Vogelzang, N. J., Carrier, R. C., George, S. L., and Gilligan, T. D. (2004). "Impact of Race on Survival in Men with Metastatic HormoneRefractory Prostate Cancer" Urology 64: 212-7.

Hargraves, J. L., Cunningham, P. J., and Hughes, R. G. (2001). "Racial and Ethnic Differences in Access to Medical Care in Managed Care Plans" HRS: Health Service Research 36(5): 853-68. 
Howard D. L. (2002). "The Meaning of Race Within Health Services Research:

Biologically Significant, Social/Political Label, or Composite Proxy?" African American Research Perspectives 8(2): 55-9.

Jackson, P. B. (2005). "Health Inequalities Among Minority Populations" Journal of Gerontology 60B(Special Issue II) 63-7.

Jatoi, I., Becher, H., Leake, C. R., (2003). "Widening Disparity in Survival Between White and African American Patients with Breast Carcinoma Treated in U. S. Department of Defense Health Care System" Cancer 98(5): 894-9.

Jemmott, L. S., Jemmott, J.B., and Hutchinson, M.K. (2001). "HIV/AIDS" in R. L. Braithwaite, and S. E. Taylor, (eds.), Health Issues in the Black Community $2^{\text {nd }}$ Ed. San Francisco, CA: Jossey-Bass.

Jernigan J. C., Trauth, J. M., Neal-Ferguson, D., and Cartier-Ulrich, C. (2001). "Factors That Influence Cancer Screening in Older African American Men and Women: Focus Group Findings" Family Community Health 24(3): 27-33.

Jewson, N. (1976). "The Disappearance of the Sick Man from Medical Cosmology 17701870" Sociology 10: 225-244.

Klassen, A. C., Juon, H., Alberg, A. J., Reid, B. C., and Meissner, H. I. (2003)

"Opportunities for Oral Cancer Screening Amoung Older African American Women Preventive Medicine 37: 499-506.

Karlson, S. and Nazroo, J. Y. (2004). "Fear of Racism and Health" Journal Epidemiological Community Health 58: 1017-8.

Kiple, K. F. (1984). The Caribbean Slave: A Biological History. New York: Cambridge University Press.

Kivisto, P. (2003). Social Theory: Roots and Branches $2^{\text {nd }}$ Ed. Los Angeles: Roxbury Publishing Company.

Krieger, N. (1999). "Embodying Inequality: A Review of Concepts Measures, and Methods for Studying Health Consequences of Discrimination" International Journal of Health Services 29(2): 295-352.

Krieger, N., Williams, D. R. and Moss, N. E., (1997). "Measuring Social Class in US Public Health Research: Concepts, Methodologies, and Guidelines" Annual Review of Public Health 18: 341-78.

Lahelma, E. (2001). "Health and Social Stratification" in W. C. Cockerham (ed). The Blackwell Companion to Medical Sociology. Malden, MA: Blackwell Publishers. 
Laditka, J. N., Laditka, S. B., and Mastanduno, M. P. (2003). "Hospital Utilization for Ambulatory Care Sensitive Conditions: Health Outcome Disparities Associated with Race and Ethnicity" Social Science and Medicine 57: 1429-41.

LaVeist, T. A. (2002). "Introduction: Why We Should Study Race, Ethnicity, and Health" in T. A. LaVeist (ed). Race, Ethnicity, and Health: A Public Health Reader San Francisco, CA: Jossy-Bass.

LaVeist, T. A. (2003). "Racial Segregation and Longevity among African Americans: An Individual-Level Analysis" HSR: Health Services Research 38(6): 1719-33.

LaVeist, T. A. and Nuru-Jeter, A. (2002) "Is Doctor-Patient Race Concordance Associated with Greater Satisfaction with Care?" Journal of Health and Social Behavior 43(3): 296-306.

Lemert, C. (2004). Social Theory: The Multicultural and Classic Readings $3^{\text {rd }}$ ed. Boulder, CO: Westview Press.

Link, B. G. and Phelan, J. (1995). "Social Conditions As Fundamental Causes of Disease" Journal of Health and Social Behavior 35 (extra issue): 80-94.

Malat, J. and van Ryn, M. (2005). "African -American Preference for Same-Race Healthcare Providers: The Role of Healthcare Discrimination" Ethnicity and Disease 15: 740-7.

Mandelblatt, J. S., Kerner, J. F., Hadley, J. Hwang, Y., Eggert, L., Johnson, L. E., and Gold, K. (2002). "Variations in Breast Carcinoma Treatment in Older Medicare Beneficiaries: Is it Black or White" Cancer 95(7): 1401-14.

Marchick, J. and Henson, D. E. (2005) "Correlations between Access to Mammography and Breast Cancer Stage at Diagnosis" Cancer 103(8): 1571-80.

Mayberry, R. M., Mili, F. and Ofili, E. (2000) "Racial and Ethnic Differences in Access to Medical Care" Medical Care Research and Review (Supplement 1): 108-45.

Mayring, P (2000). "Qualitative Content Analysis" Forum Qualitative Sozialforschung / Forum: Qualitative Social Research [On-line Journal], 1(2). Available at: http://www.qualitative-research.net/fqs-texte/2-00/2-00mayring-e.htm [Mar. 3, 2007].

McGuire, V., Herrinton, L., and Whittemore, A. S. (2002). "Race, Epithelial Ovarian Cancer Survival, and Membership in a Large Health Maintenance Organization" Epidemiology 13(2): 231-4. 
McKinlay, J. B. and McKinlay, S. J. (1977). "The questionable effect of medical measures on the decline of mortality in the United States in the twentieth century." Milbank Memorial Fund Quarterly 55: 405-428.

Miller, J. A. G., Rege, R. V., Ko, C. Y., and Livingston, E. H. (2004). "Health Care Access and Poverty Do Not Explain the Higher Esophageal Cancer Mortality in African American" The American Journal of Surgery 188: 22-6.

Mullahy, J., Robert, S. and Wolfe, B. (2007) "Health, Income, and Inequality" in D. B. Grusky and S. Szelenyi (eds.) The Inequality Reader: Contemporary and Foundational Readings in Race, Class, and Gender. Cambridge, MA: Westview.

Murdock, J. M. and Gluckman, J. L. (2001). "African American and White Head and Neck Carcinoma Patients in a University Medical Center Setting" Cancer Supplement 91(1): 279-83.

NLM (National Library of Medicine). (2007). United States National Library of Medicine by National Institute of Health [Online]. Available: <http://www.nlm.nih.gov/> [March 12, 2007].

Nettleton, S. (2006). The Sociology of Health and Illness ( $2^{\text {nd }}$ Ed.). Cambridge: Polity.

Office of Management and Budget (OMB) (1997) "Standards for Maintaining, Collecting, and Presenting Federal Data on Race and Ethnicity" Federal Register 62 FR 58781-58790 [Online] Available: <www.whitehouse.gov/omb/fedreg/1997standards.html> [February, 20, 2007].

Okigbo, C. Okigbo, C.A., Hall, W.B., and Ziegler, D. (2002). "The HIV/AIDS Epidemic in African American Communities: Lessons from UNAIDS and Africa." Journal of Black Studies 32(6): 615-53.

Oliver M. N., Muntaner C. "Researching health inequities among. African Americans: The imperative to understand social class" International Journal of Health Services 35:485-498.

O’Malley, M. S., Earp, J. A. L., Hawley, S. T., Schell, M. J., Mathews, H. F., and Mitchell, J. (2001). "The Association of Race/Ethnicity Socioeconomic Status, and Physician Recommendation for Mammography: Who Gets the Message About Breast Cancer Screening?” American Journal Public Health 91(1): 49-54.

Otero-Sabogal, R., Owens, D., Canchola, J., Golding, J. M., Tabnak, F., and Fox, P. (2004). "Mammography Rescreening Among Woman of Diverse Ethnicities: Patient, Provider, and Health Care System Factors" Journal of Health Care for the Poor and Underserved 15: 390-412.

Parsons, T. (1951). The Social System. Glencoe, IL: The Free Press. 
Pearl, M. Braverman, P., and Abrams, B. (2001). "The Relationship of Neighborhood Socioeconomic Characteristics to Birthweight Among 5 Ethnic Groups in California" American Journal of Public Health 91(11): 1808-14.

Phimister, E. G. (2003). "Medicine and the Racial Divide" New England Journal of Medicine. 348(12): 1081-2.

Pescosolido B. A. and Kronenfeld J. J. (1995) "Health, Illness, and Healing in an Uncertain Era: Challenges from and for Medical Sociology" Journal of Health and Social Behavior, Vol. 35, Extra Issue: pp. 5-33.

Qureshi, M., Thacker, H. L., Litaker, D. G., and Kippes, C. (2000). "Differences in Breast Cancer Screening Rates: An Issue Ethnicity or Socioeconomics?" Journal of Women's Health and Gender-Based Medicine 6: 1025-31.

Randall, V. (2006). Dying While Black: An Indept Look at a Crisis in the American Healthcare System

Rawl, S. M., Campion, V. L., Menon, U., and Foster, J. L. (2000). "The Impact of Age and Race on Mammography Practices" Health Care for Women International 21: 583-97.

Reed, A. (2005). "Making Sense of Race, I: The Ideology of Race, the Biology of Human Variation and the Problem of Medical and Public Health Research" Journal of Race and Policy 11-42.

Richards, R. J. and Reker, D. M. (2002). "Racial Differences in Use of Colonoscopy, Sigmoidoscopy and Barium Enema in Medical Beneficiaries" Digestive Diseases and Sciences 47(12): 2715-9.

Robert, S. A. and House, J. S. (2000) "Socioeconomic inequalities in Health an Enduring Sociological Problem" in C. E. Bird, P. Conrad, and A. M. Fremont (eds). Handbook of Medical Sociology ( $5^{\text {th }}$ Ed.) Upper Saddle River, NJ: Prentice Hall.

Rolnick, S., Alford, S. H., Kucera, G. P., Fortman, K., Yood, M. U., Jankowski, M. and Johnson, C. C. (2005). "Racial and Age Differences in Colon Examination Surveillance Following a Diagnosis of Colorectal Cancer" Journal of the National Cancer Institute Monographs 35: 96-101.

Root, M. (2003). "The Use of Race as a Proxy for Genetic Differences" Philosophy of Science 70: 1173-83. 
Rosenberg, L., Wise, L. A., Palmer, J. R., Horton, N. J. and Adams-Campbell, L. L. (2005). "A Multilevel Study of Socioeconomic Predictors of Regular mammography Use Among African American Women" Cancer Epidemiology, Biomarkers \& Prevention 14(11): 2628-33.

Royer-Schaler, R. Chen, S., Zang, E., Vivacqua, R. J., and Bynoe, M. (2003). "Does Access to Screening Through Health Maintenance Organization Membership Translate Into Improved Breast Cancer Outcomes for African American Patients?" Journal of the American Medical Women's Association 58: 154-8.

Rundell, J. (2001) "Modernity, Enlightenment, Revolution and Romanticism: Creating Social Theory" in G. Ritzer and B. Smart (eds.) Handbook of Social Theory. Thousand Oaks, CA: Sage.

Ryn, M. Burgess, D., Malat, J., and Griffin, J. (2006) “Physicians' Perceptions of Patients Social and Behavioral Characteristics and Race Disparities in Treatment Recommendations for Men with Coronary Artery Disease" American Journal of Public Health 96(2): 351-7.

Satcher, D., Fryer, G. E., McCann, J., Troutman, A., Woolf, S. H., and Rust, G. (2005). "What If We Were Not Equal? A Comparison of The Black-White Mortality Gap in 1960-2000" Health Affairs 24(2): 459-464.

Schneider, E. C., Zaslavksy, A. M. and Epstein, A. M. (2002) "Racial Disparities in the Quality of Car for Enrollees in Medicare Managed Care" JAMA: Journal of American Medical Association 287(10): 1288-94.

Scott, J. (2007). "Life at the Top in America Isn't Just Better, It's Longer" in D. B. Grusky and S. Szelenyi (eds.) The Inequality Reader: Contemporary and Foundational Readings in Race, Class, and Gender. Cambridge, MA: Westview.

Selvin, E. and Young, K. M. (2003). "Breast and Cervical Cancer Screening: Sociodemographic Predictors Among White, Black, and Hispanic Women" American Journal of Public Health (93)4: 618-23.

Semmes, C. E. (1996). Racism, Health, and Post-Industrialism: A Theory of African American Health. Westport, CN: Praeger.

Shields, A. E., Fortun, M., Hammonds, E. M., King, P. A., Lerman, C., Rapp, R., and Sullivan P. F., (2005) "The Use of Race Variables in Genetic Studies of Complex Traits and the Goal of Reducing Health Disparities: A Transdisciplinary Perspective" American Psychologist 60(1): 77-103.

Shilling, C. (2002). "Culture, the 'sick role' and the Consumption of Health" British Journal of Sociology, 53(4): 621-638. 
Silverman, D. T., Hoover, R. N., Brown, L. M., Swanson, G. M., Schiffman, M., Greenberg, R. S., Hayes, R. B., Lillemoe, K. D., Schoenberg, J. B., Schwartz, A. G., Liff, G., Pottern, L. M., and Fraumeni, J. F. (2002). "Why Do Black American Have a Higher Risk of Pancreatic Cancer Than White Americans?" Epidemiology 14(1): 45-54.

Singh, G. K., Miller, B. A., Hankey., B. F., and Edwards, B. K. (2004). "Persistent Area Socioeconomic Disparities in U. S. Incidence of Cervical Cancer, Mortality, Stage, and Survival, 1975-2000" Cancer 101(5): 1051-7.

Smaje, C. (2000a). "A Place for Race?: Medical Sociology and the critique of racial ideology" in S. J. Williams, J. Gabe, and M. Calnan (eds.) in Health, Medicine and Society: Key Theories, Future Agendas. London and New York: Routledge.

Smaje, C. (2000b). "Race, Ethnicity, and Health" in C. E. Bird, P. Conrad, and A. M. Fremont (eds). Handbook of Medical Sociology $\left(5^{\text {th }}\right.$ Ed.) Upper Saddle River, NJ: Prentice Hall.

Smedley, B. D., Stith, A. Y., and Nelson A. R., (2003). Unequal Treatment: Confronting Racial and Ethnic Disparities in Health. Washington, DC: National Academies Press

Spalter-Roth, R. Lowenthal, T. A., and Rubio, M. (2005) "Race, Ethnicity, and the Health of Americans" ASA: American Sociological Association p. 1-16.

Straus, R. (1957). "The Nature and Status of Medical Sociology" American Sociological Review 22: 200-204.

Stone, J. (2002). "Race and Healthcare Disparities: Overcoming Vulnerability" Theoretical Medicine 23: 499-518.

Syme, S. L. and Yen, I. H. (2000). "Social Epidemiology and Medical Sociology: Different Approaches to the Same Problem" in C. E. Bird, P. Conrad, and A. M. Fremont (eds). Handbook of Medical Sociology $\left(5^{\text {th }}\right.$ Ed.) Upper Saddle River, NJ: Prentice Hall.

Takeuchi, D. T. and Gage, S. L. (2003). "What to do with Race?: Changing Notions of Race in the Social Sciences" Culture, Medicine and Psychiatry 27: 435-45.

Taylor, S. (2001) "The Health Status of Black Women" in R. Braithwaite and S. Taylor (eds). Health Issues in the Black Community $2^{\text {nd }}$ Ed. San Francisco, CA: JosseyBoss. 
Tashiro, C. J., (2005). "The Meaning of Race in Healthcare and Research - Part 2 Current Controversies and Emerging Research" Pediatric Nursing 31(4): 305-8.

Thatai, L. C., Benerjee, M., Lai, Z., and Vaishampayan, U. (2004). "Racial Disparities in Clinical Course and Outcome of Metastatic Androgen-Independent Prostate Cancer" Urology 64(4): 738-43.

Thompson, W. E. and Hickey, J. V. (2002). Society in Focus: An Introduction to Sociology $4^{\text {th }}$ Ed. Boston: Allyn and Bacon.

Tucker, R. H. (2002) Classical Social Theory. Malden, MA: Blackwell Publishers

Turner, J. H. (1986). The Structure of Social Theory $\left(4^{\text {th }}\right.$ Ed). Chicago, IL: The Dorsey Press.

Verghese, A (1995) My Own Country: A Doctor's Story. New York: Vintage Books.

Vallerand, A. H., Hasenau, S., Templin, T., and Collins-Bohler, D. (2005). "Disparities Between Black and White Patients with Cancer Pain: The Effect of Perception of Control over Pain" Pain Medicine (6)3: 242-50.

Van Ryn, M. and Burke, J. (2000). "The Effect of Patient Race and Socio-Economic Status on Physicians Perception of Patients" Social Science and Medicine 50: 813-828.

Weitz, R. (2004). The Sociology of Health, Illness, and Health Care $\left(3^{\mathrm{rd}}\right.$ Ed). Belmont, CA: Wadsworth.

Williams, D. R. (1994). "The Concept of Race in Health Services Research: 1966-1990" HSR Health Services Research 29(3): 261-74.

Williams, D. R. (1997). "Race and Health: Basic Questions, Emerging Directions" Annuals of Epidemiology 7(5): 322-33.

Williams, D. R. (1999). "Race, Socioeconomic Status, and Health: The Added Effects of Racism and Discrimination" Annals of New York Academy of Science 896: 173188

Williams, D. R. (2003). "The Health of Men: Structured Inequalities and Opportunities" American Journal of Public Health 93(5): 724-31.

Williams, D. R., (2005). "The Health of U. S. Racial and Ethnic Populations" Journals of Gerontology 60B(Special Issue II): 53-62.

Williams, D. R. and Collins C. (1995). "US Socioeconomic and Racial Differences in Health: Patterns and Explanations" Annual Review of Sociology 21: 349-386. 
Williams, D. R. and Collins C. (2001). "Racial Residential Segregation: A Fundamental Cause of Racial Disparities in Health" Public Health Reports, Sept-Oct., 16

Williams, D. R. and Collins C. (2004). "Reparations: A Viable Strategy to Address the Enigma of African American Health" American Behavioral Scientist 47(7): 9771000.

Williams, D. R. and Jackson P. B. (2005). "Social Sources of Racial Disparities in Health" Health Affairs 24(2): 325-34.

Williams, D. R., Neighbors, H. W., Jackson, J. S. (2003). "Racial/Ethnic Discrimination and Health: Findings from Community Studies" American Journal of Public Health 93(2): 200-8.

Williams, D. R., Yu, Y., Jackson, J. S., and Anderson, N. B. (1997). "Racial Differences in Physical and Mental Health: Socio-economic Status, Stress and Discrimination" Journal of Health Psychology 2(3): 335-51.

Williams, S. J., Gabe, J., and Calnan, M., (2000). "Introduction - Health, medicine and society key theories, future agendas" in S. J. Williams, J. Gabe, and M. Calnan (eds.) in Health, Medicine and Society: Key Theories, Future Agendas. London and New York: Routledge.

Wilkinson, R. and Marmot, M. (2003) The Social Determinants of Health: Solid Facts $2^{\text {nd }}$ Ed.: World Health Organization (WHO).

Winant, H. (1994). Racial Conditions: Politics, Theory, Comparisons. Minneapolis, MN: University of Minnesota Press.

Winker, M. A., (2004). "Measuring Race and Ethnicity: Why and How?" Journal of American Medical Association 292(13): 1612-14.

Young, R. F. and Severson, R. K. (2005). "Breast Cancer Screening barriers and mammography Completion in Older Minority Women" Breast Cancer Research and Treatment 89: 111-8. 
APPENDIX 
TABLE 1 - Selected Journal Articles on Race and Health Differentials by Research Design, Sample Population, Focus of Analysis, and Analytic Measure of Social Class

\begin{tabular}{|c|c|c|c|c|}
\hline \multirow[b]{2}{*}{$\begin{array}{l}\text { Article; } \\
\text { Author name, year }\end{array}$} & \multirow[b]{2}{*}{$\begin{array}{l}\text { Research } \\
\text { Design } \\
\end{array}$} & [2] & [3] & \multirow{2}{*}{\begin{tabular}{l}
\multicolumn{1}{c}{$[4]$} \\
Analytic \\
Measure of \\
Social Class
\end{tabular}} \\
\hline & & $\begin{array}{l}\text { Sample } \\
\text { Population }\end{array}$ & $\begin{array}{l}\text { Focus of } \\
\text { Analysis }\end{array}$ & \\
\hline Ashton et al., 2003 & Qualitative & AA and Hisp & Causes & $\mathrm{N} / \mathrm{A}$ \\
\hline Balsa and McGuire, 2003 & Qualitative & All Races & Causes & N/A \\
\hline Boulware et al., 2003 & Quantitative & $\begin{array}{l}\text { AA \& Wht } \\
\text { ages } 18-75\end{array}$ & Causes & $\begin{array}{l}\text { Ed lev; HH } \\
\text { income }\end{array}$ \\
\hline Brown et al., 2000 & Qualitative & $\mathrm{AA}$ & Causes & $\begin{array}{l}\text { HH income; } \\
\text { Poverty Status }\end{array}$ \\
\hline Copeland, 2005 & Qualitiative & AA & Both & N/A \\
\hline Geronimus, 2000 & Qualitative & $\begin{array}{l}\text { impoverished } \\
\text { AA }\end{array}$ & Causes & Poverty status \\
\hline Hargraves et al., 2001 & Quantitative & $\begin{array}{l}\text { AA, Hisp, } \\
\text { Wht, } \leq 65 \text {, } \\
\text { insured }\end{array}$ & Both & $\begin{array}{l}\text { HH Income, Ed } \\
\text { lev }\end{array}$ \\
\hline Jackson, 2005 & Qualitative & AA \& Wht & Both & $\begin{array}{l}\text { Ed lev; Income; } \\
\text { Employment; }\end{array}$ \\
\hline LaVeist, 2003 & Qualitative & $\begin{array}{l}\text { AA ages } 18- \\
101\end{array}$ & Causes & Ed lev \\
\hline Laditka et al., 2003 & Qualitative & $\begin{array}{l}\text { AA, Hisp, } \\
\text { Wht } \geq 18\end{array}$ & Outcomes & N/A \\
\hline
\end{tabular}


TABLE 1 (Cont.) - Selected Journal Articles on Race and Health Differentials by Conceptualization of Race, Race/Class Intersection, Explantion of Racial Disparities, Primary Causal Factors

\begin{tabular}{|c|c|c|c|c|}
\hline & {$[5]$} & [6] & [7] & {$[8]$} \\
\hline $\begin{array}{l}\text { Article; } \\
\text { Author name, year }\end{array}$ & $\begin{array}{l}\text { Use of Race: } \\
\text { Concept/Variable }\end{array}$ & $\begin{array}{l}\text { Race/Class } \\
\text { Intersection } \\
\end{array}$ & $\begin{array}{l}\text { Explanation of } \\
\text { Racial Disparities }\end{array}$ & $\begin{array}{l}\text { Primary } \\
\text { Casual Factors } \\
\end{array}$ \\
\hline Ashton et al., 2003 & Variable & No & HB & $\begin{array}{l}\text { Better } \\
\text { communication } \\
\text { between Physician } \\
\text { and Patient }\end{array}$ \\
\hline Balsa and McGuire, 2003 & Variable & No & SC & Racism \\
\hline Boulware et al., 2003 & Concept & Yes & SC; PS & $\begin{array}{l}\text { Physician-Patient } \\
\text { Relationship and } \\
\text { Trust in Medical } \\
\text { providers and } \\
\text { institutions }\end{array}$ \\
\hline Brown et al., 2000 & Concept & Yes & SC; SES & Health Insurance \\
\hline Copeland, 2005 & Variable & No & SC; PS & $\begin{array}{l}\text { Racism, Health } \\
\text { Insuarance, }\end{array}$ \\
\hline Geronimus, 2000 & Concept & Yes & SC; PS & $\begin{array}{l}\text { Racism: Racial } \\
\text { Segregation }\end{array}$ \\
\hline Hargraves et al., 2001 & Concept & Yes & SC & Health Insurance \\
\hline Jackson, 2005 & Concept & Yes & SC; PS & Racism \\
\hline LaVeist, 2003 & Concept & Yes & $\mathrm{SC}$ & $\begin{array}{l}\text { Racism, Racial } \\
\text { Segragation }\end{array}$ \\
\hline Laditka et al., 2003 & Variable & No & $\mathrm{SC}$ & $\begin{array}{l}\text { Primary Care } \\
\text { Provider }\end{array}$ \\
\hline
\end{tabular}


TABLE 2 - Selected Journal Articles on Race and Health Differentials by Research Design, Sample Population, Focus of Analysis, and Conceptualization of Race

\begin{tabular}{|c|c|c|c|c|}
\hline & {$[1]$} & {$[2]$} & [3] & 4] \\
\hline $\begin{array}{l}\text { Article; } \\
\text { Author name, year }\end{array}$ & $\begin{array}{l}\text { Research } \\
\text { Design }\end{array}$ & $\begin{array}{l}\text { Sample } \\
\text { Population }\end{array}$ & $\begin{array}{l}\text { Focus of } \\
\text { Analysis }\end{array}$ & $\begin{array}{l}\text { Analytic } \\
\text { Measure of } \\
\text { Social Class }\end{array}$ \\
\hline Malat and van Ryn, 2005 & Quantitative & AA & Causes & $\begin{array}{l}\text { Ed lev, } \mathrm{HH} \\
\text { income }\end{array}$ \\
\hline
\end{tabular}

Satcher et al., $2005 \quad$ Quantitative AA \& Wht Outcomes N/A

Schneider et al., 2002

Spalter et al., 2005

Stone, 2002

van Ryn and Burke, 2000

Williams, 2003

Williams, 2005

Williams and Collins, 2004

Williams and Jackson, 2005
Quantitative

Qualitative

Qualitative

Quantitative

AA \& Wht

Causes

Ed lev; Income

Qualitative

All Races

Both

Ed lev; Income

Qualitative

All Races

Causes

Ed lev; Income;

Employment;

Poverty Rate

Ed lev; Income;

Qualitative

AA

Both

AA

Causes

Ed lev; Income 
TABLE 2 (Cont.) - Selected Journal Articles on. Race and Health Differentials by Conceptualization of Race, Race/Class Intersection, Explantion of Racial Disparities, Primary Causal Factors

\begin{tabular}{|c|c|c|c|c|}
\hline & [5] & [6] & [7] & {$[8]$} \\
\hline Article (Author name, year) & $\begin{array}{l}\text { Use of Race: } \\
\text { Concept/Variable }\end{array}$ & $\begin{array}{l}\text { Race/Class } \\
\text { Intersection }\end{array}$ & $\begin{array}{l}\text { Explanation of } \\
\text { Racial Disparities }\end{array}$ & $\begin{array}{l}\text { Primary } \\
\text { Casual Factors }\end{array}$ \\
\hline Malat and van Ryn, 2005 & Concept & Yes & SC & $\begin{array}{l}\text { Racism, Doctor- } \\
\text { Patient } \\
\text { Relationship }\end{array}$ \\
\hline Satcher et al., 2005 & Variable & No & SC & $\begin{array}{l}\text { Equaltity in Income } \\
\text { distribution, Health } \\
\text { Insurance }\end{array}$ \\
\hline Schneider et al.,2002 & Concept & Yes & SC & $\begin{array}{l}\text { Physician-Patient } \\
\text { Relationship }\end{array}$ \\
\hline Spalter et al., 2005 & Concept & Yes & SC & $\begin{array}{l}\text { Racism; Health } \\
\text { Insurance }\end{array}$ \\
\hline Stone, 2003 & Concept & Yes & PS; SC & $\begin{array}{l}\text { Racism; Health } \\
\text { Care } \\
\text { Administrations }\end{array}$ \\
\hline van Ryn and Burke, 2000 & Concept & Yes & SC; PS & $\begin{array}{l}\text { Racism; Physician- } \\
\text { Patient } \\
\text { Relationship }\end{array}$ \\
\hline Williams, 2003 & Concept & Yes & SC; PS & $\begin{array}{l}\text { Racism; Racial } \\
\text { Segregation; Health } \\
\text { Insurance }\end{array}$ \\
\hline Williams, 2005 & Concept & Yes & SC; PS & Racism \\
\hline Williams and Collins, 2004 & Concept & Yes & SC; PS; SES & $\begin{array}{l}\text { Racism; Racial } \\
\text { Segregation }\end{array}$ \\
\hline Williams and Jackson, 2005 & Concept & Yes & SC; PS & $\begin{array}{l}\text { Racism: Stress; } \\
\text { Racial Segregation; } \\
\text { health policy }\end{array}$ \\
\hline
\end{tabular}


TABLE 3 - Selected Journal Articles on Race and Cancer by Sample Population, Focus of Analysis, and Analytic Measure of Social Class

\begin{tabular}{|c|c|c|c|}
\hline Article (Author name, year) & $\begin{array}{l} \\
\text { Sample } \\
\text { Population }\end{array}$ & $\begin{array}{l}\frac{[2]}{\text { Focus of }} \\
\text { Analysis }\end{array}$ & \begin{tabular}{l|l} 
& {$[3]$} \\
$\begin{array}{l}\text { Analytic Measure } \\
\text { of Social Class }\end{array}$ \\
\end{tabular} \\
\hline Anderson et al., 2002 & $\begin{array}{l}\text { Convenience: AA and Hisp } \\
\text { economically disadvantaged }\end{array}$ & Outcomes & Ed lev, Employment \\
\hline Baldwin et al., 2005 & $\begin{array}{l}\text { Convenience: AA \& Wht insured } \\
\text { ages } \geq 66 \text { years old }\end{array}$ & Causes & Median income, Ed lev \\
\hline Bibb, 2001 & $\begin{array}{l}\text { Convenience: AA \& Wht Females, } \\
\text { ages } 25-97\end{array}$ & Causes & $\begin{array}{l}\text { Income - using Military } \\
\text { Ranking }\end{array}$ \\
\hline Brooks et al., 2000 & Convenience: AA \& Wht Females & Outcomes & N/A \\
\hline Cooper and Koroukian, 2004 & $\begin{array}{l}\text { Convenience: } A A \text { and Wht insured } \\
\geq 65 \text { years old }\end{array}$ & Causes & N/A \\
\hline Davis et al. 2005 & Convenience: AA Females & Causes & Edlev; Mo Income \\
\hline Farley et al., 2001 & Convenience: All Races Females & Outcomes & $\begin{array}{l}\text { Income - using Military } \\
\text { Ranking }\end{array}$ \\
\hline Field et al., 2005 & $\begin{array}{l}\text { Convenience: } A A \& \text { Wht Females } \geq \\
20 \text { at time of diagnosis; insured }\end{array}$ & Outcomes & N/A \\
\hline Freedland et al., 2000 & Convenience: AA \& Wht Males; & Outcomes & N/A \\
\hline Foote, 2003 & Random: AA \& Wht & Outcomes & N/A \\
\hline Govindarajan et al., 2003 & $\begin{array}{l}\text { Convenience: AA \& Wht } 218 \text { years } \\
\text { old }\end{array}$ & Outcomes & $\begin{array}{l}\text { Ed lev; Income; } \\
\text { Poverty Status }\end{array}$ \\
\hline Green et al., 2005 & $\begin{array}{l}\text { Convenience: AA Females ages } 52- \\
79\end{array}$ & Causes & $\begin{array}{l}\text { HH Annual income; Ed } \\
\text { lev }\end{array}$ \\
\hline
\end{tabular}


TABLE 3 (Cont.) - Selected Journal Articles on Race and Cancer byConceptualization of Race, Race/Class Intersection, Explantion of Racial Disparities, Primary Causal Factors

\begin{tabular}{|c|c|c|c|c|}
\hline Article (Author name, year) & $\begin{array}{l}\text { [4] } \\
\text { Use of Race: } \\
\text { ConceptNariable }\end{array}$ & $\begin{array}{c}5] \\
\text { Race/Class } \\
\text { Intersection }\end{array}$ & $\begin{array}{l}6] \\
\text { Explanation of Racial } \\
\text { Disparities }\end{array}$ & 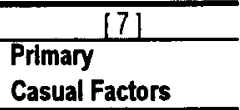 \\
\hline Anderson et al., 2002 & Concept & Yes & $\mathrm{HB} ; \mathrm{SC}$ & $\begin{array}{l}\text { Availablity of adequate } \\
\text { treatment; Education } \\
\text { on Treatment }\end{array}$ \\
\hline Baldwin et al., 2005 & Concept & Yes & SC & Social Support \\
\hline Bibb, 2001 & Concept & Yes & SES; SC & Racism \\
\hline Brooks et al., 2000 & Variable & No & SES & Health Insurance \\
\hline Cooper and Koroukian, 2004 & Variable & No & SC & $\begin{array}{l}\text { Racism; Screening } \\
\text { Procedures }\end{array}$ \\
\hline Davis et al., 2005 & Variable & No & $\mathrm{HB}$ & $\begin{array}{l}\text { Race; Physician- } \\
\text { Patient interaction }\end{array}$ \\
\hline Farley et al., 2001 & Variable & No & SC & $\begin{array}{l}\text { No dispartiy was } \\
\text { observed }\end{array}$ \\
\hline Field et al., 2005 & Variable & No & SC & Racism \\
\hline Freedland et al., 2000 & Variable & No & $N / A$ & $\begin{array}{l}\text { No racial dispartiey } \\
\text { was observed }\end{array}$ \\
\hline Foote, 2003 & Variable & No & $\mathrm{HB}$ & $\begin{array}{l}\text { Screening Procedures; } \\
\text { Healthy Behavior }\end{array}$ \\
\hline Govindarajan et al., 2003 & Concept & Yes & SC & Racism \\
\hline Green et al., 2005 & Concept & Yes & $\mathrm{SC}$ & $\begin{array}{l}\text { Education; Screening } \\
\text { Procedures }\end{array}$ \\
\hline
\end{tabular}


TABLE 4 - Selected Journal Articles on Race and Cancer by Sample Population, Focus of Analysis, and Analytic Measure of Social Class

\begin{tabular}{|c|c|c|c|}
\hline & [1] & [2] & {$[3]$} \\
\hline Article (Author name, year) & $\begin{array}{l}\text { Sampla } \\
\text { Population }\end{array}$ & $\begin{array}{l}\text { Focus of } \\
\text { Analysis }\end{array}$ & $\begin{array}{l}\text { Analytic Measure of } \\
\text { Soclal Class }\end{array}$ \\
\hline Green and Kelly, 2004 & $\begin{array}{l}\text { Convenience: AA from low income } \\
\text { housing } \geq 50\end{array}$ & Causes & Ed lev; Annual Income \\
\hline Gwyn et al., 2004 & $\begin{array}{l}\text { Convenience: AA \& Wht Females } \\
\text { ages } 20-54\end{array}$ & Outcomes & Ed level; Poverty index \\
\hline Halabi et al., 2004 & Convenience: AA \& Wht Male & Outcomes & Ed lev; Employment \\
\hline Jatoi et al., 2003 & Convenience: AA \& Wht & Outcomes & N/A \\
\hline Jernigan et al., 2001 & Convenience: $A A \geq 50$ years old & Causes & N/A \\
\hline Klassen et al., 2003 & Concenience: AA Females $\geq 45$ & Causes & $\begin{array}{l}\text { Ed lev; HH Income; } \\
\text { Employmel }\end{array}$ \\
\hline Mandelblatt et al., 2002 & $\begin{array}{l}\text { Random: AA \& Wht; insured; } \geq 67 \\
\text { years old }\end{array}$ & Outcomes & $\begin{array}{l}\text { Ed lev; Per Capita } \\
\text { Income; \% } \\
\text { Unemployed; Median } \\
\text { Income }\end{array}$ \\
\hline Marchick and Henson, 2005 & $\begin{array}{l}\text { Convenience: AA \& Wht Females } \\
218 \text { years old }\end{array}$ & Causes & N/A \\
\hline McGuire et al. , 2002 & Convenience: AA \& Wht Females & Outcomes & N/A \\
\hline Miller et al., 2004 & Random: All Races & Outcomes & $\begin{array}{l}\text { Poverty; Ed lev; } \\
\text { Employment }\end{array}$ \\
\hline Murdock and Gluckman, 2001 & Convenience : AA \& Wht ages 39-87 & Outcomes & N/A \\
\hline O'Malley et al., 2001 & $\begin{array}{l}\text { Random: AA \& Wht Females } \geq 50 \\
\text { years old }\end{array}$ & Causes & Ed lev; Family Income \\
\hline Otero-Sabogal et al., 2004 & $\begin{array}{l}\text { Random: All Races } \geq 50 \text { years old } \\
\text { non-insured Females }\end{array}$ & Causes & $\begin{array}{l}\text { Ed lev; Employment; } \\
\text { HH income }\end{array}$ \\
\hline
\end{tabular}


TABLE 4 (Cont.) - Selected Journal Articles on Race and Cancer byConceptualization of Race, Race/Class Intersection, Explantion of Racial Disparities, Primary Causal Factors

\begin{tabular}{|c|c|c|c|c|}
\hline Article (Author name, year) & $\begin{array}{l}\frac{[4]}{\text { Use of Race: }} \\
\text { ConceptNarlable }\end{array}$ & $\begin{array}{l}5] \\
\text { Class/Race } \\
\text { Intersection }\end{array}$ & $\begin{array}{l}{[6]} \\
\text { Explanation of Racial } \\
\text { Disparlties }\end{array}$ & $\begin{array}{l}\text { [7] } \\
\text { Primary } \\
\text { Casual Factors }\end{array}$ \\
\hline Green and Kelly, 2004 & Concept & Yes & $\mathrm{HB}$ & $\begin{array}{l}\text { Education and } \\
\text { Screening }\end{array}$ \\
\hline Gwyn et al., 2004 & Concept & Yes & $\mathrm{HB} ; \mathrm{SC}$ & Screening Procedures \\
\hline Halabi et al., 2004 & Variable & No & $\mathrm{N} / \mathrm{A}$ & $\begin{array}{l}\text { No racial disparity was } \\
\text { observed }\end{array}$ \\
\hline Jatoi ef al., 2003 & Variable & No & SC & $\begin{array}{l}\text { Healthy Behavior; } \\
\text { Physcian--Patient } \\
\text { Relationship }\end{array}$ \\
\hline Jernigan et al., 2001 & Variable & No & $\mathrm{HB} ; \mathrm{SC}$ & $\begin{array}{l}\text { Social Support; } \\
\text { Physcian--Patient } \\
\text { Relationship }\end{array}$ \\
\hline Klassen et al., 2003 & Concept & Yes & $\mathrm{HB}$ & $\begin{array}{l}\text { Screening Procdures; } \\
\text { Healthy Behavior }\end{array}$ \\
\hline Mandelblatt et al., 2002 & Concept & Yes & $\mathrm{HB} ; \mathrm{PS}$ & $\begin{array}{l}\text { Racism; Physcian-- } \\
\text { Patient Relationship }\end{array}$ \\
\hline Marchick and Henson, 2005 & Variable & No & SC & $\begin{array}{l}\text { Access to Care (\# of } \\
\text { Care Faclities and } \\
\text { Distance to Care } \\
\text { Facilities) }\end{array}$ \\
\hline McGuire et al. , 2002 & Variable & No & $\mathrm{SC}$ & Racism \\
\hline Miller et al., 2004 & Concept & Yes & $\mathrm{HB} ; \mathrm{SC}$ & $\begin{array}{l}\text { Health Care Delivery; } \\
\text { Healthy Behavior; }\end{array}$ \\
\hline Murdock and Gluckman, 2001 & Variable & No & SC & $\begin{array}{l}\text { Racism; Healthy } \\
\text { Behavior }\end{array}$ \\
\hline O'Malley et al., 2001 & Variable & No & SES & $\begin{array}{l}\text { Observed no racial diff } \\
\text { but did observe } \\
\text { difference in SES }\end{array}$ \\
\hline Otero-Sabogal et al., 2004 & Variable & No & SC & $\begin{array}{l}\text { Health Insurance; } \\
\text { Physician-Patient } \\
\text { Relationship }\end{array}$ \\
\hline
\end{tabular}


TABLE 5 - Selected Journal Articles on Race and Cancer by Sample Population, Focus of Analysis, and Analytic Measure of Social Class

\begin{tabular}{|c|c|c|c|}
\hline Article (Author name, year) & $\begin{array}{l}\text { Sample } \\
\text { Population } \\
\end{array}$ & $\begin{array}{l}\frac{[2]}{\text { Focus of }} \\
\text { Analysis } \\
\end{array}$ & $\begin{array}{l}{[3]} \\
\text { Analytic Measure of } \\
\text { Soclal Class }\end{array}$ \\
\hline Qureshi et al., 2000 & $\begin{array}{l}\text { Convenience: All Races, Females } \\
40-49 \text { years old }\end{array}$ & Outcomes & Ed lev; HH income \\
\hline Rawl et al., 2000 & $\begin{array}{l}\text { Convenience: AA \& Wht Females } \\
\text { insured }\end{array}$ & Causes & Ed lev; Income \\
\hline Richards and Reker, 2002 & Random: AA \& Wht 265 insured & Causes & Income \\
\hline Rolnick et al., 2005 & Convenience: AA \& Wht insured & Outcomes & N/A \\
\hline Rosenberg et al., 2005 & $\begin{array}{l}\text { Convenience: AA Females ages } 21 \text { - } \\
69\end{array}$ & Causes & $\begin{array}{l}\text { HH income; Ed lev; } \\
\text { Neighborhood SES }\end{array}$ \\
\hline Royak-Schaler et al., 2003 & Convenience: AA \& Wht & Outcomes & $N / A$ \\
\hline Silverman et al., 2002 & Random: AA \& Wht ages $30-79$ & Causes & Edlev; Income \\
\hline Singh et al., 2004 & Random: Females of All Races & Causes & Ed lev; Poverty Status \\
\hline Selvin and Brett, 2003 & $\begin{array}{l}\text { Convenience: AA, Hisp \& Wht } \\
\text { Females; ages } 40-64\end{array}$ & Causes & Income; Ed lev \\
\hline Thatai et al., 2004 & Convenience: AA \& Wht Males & Outcomes & $\mathrm{N} / \mathrm{A}$ \\
\hline Young and Severson, 2005 & $\begin{array}{l}\text { Convenience: AA Females ages } 40 \text { - } \\
64 \text {; low-moderate income; non- } \\
\text { insured }\end{array}$ & Causes & Income \\
\hline Vallerand et al. , 2005 & $\begin{array}{l}\text { Random: All Races } 218 \text {, but only } \\
\text { AA \& Wht used in analysis }\end{array}$ & Outcomes & Ed lev, Employment \\
\hline
\end{tabular}


TABLE 5 (Cont.) - Selected Journal Articles on Race and Cancer byConceptualization of Race, Race/Class Intersection, Explantion of Racial Disparities, Primary Causal Factors

\begin{tabular}{|c|c|c|c|c|}
\hline & [4] & {$[5]$} & {$[6]$} & [7] \\
\hline Article (Author name, year) & $\begin{array}{l}\text { Use of Race: } \\
\text { ConceptNarlable }\end{array}$ & $\begin{array}{l}\text { Class/Race } \\
\text { Intersection }\end{array}$ & $\begin{array}{l}\text { Explanation of Racial } \\
\text { Disparities }\end{array}$ & $\begin{array}{l}\text { Primary } \\
\text { Casual Factors }\end{array}$ \\
\hline Qureshi et al., 2000 & Variable & No & SES; HB & $\begin{array}{l}\text { Health Insurance; } \\
\text { Healty Behavior, } \\
\text { Screening Procedures }\end{array}$ \\
\hline Rawl et al., 2000 & Concept & Yes & $\mathrm{HB}$ & $\begin{array}{l}\text { Screening Procedures; } \\
\text { Education on Health } \\
\text { Practices }\end{array}$ \\
\hline Richards and Reker, 2002 & Concept & Yes & SC & Racism \\
\hline Rolnick et al., 2005 & Variable & No & SC & Racism \\
\hline Rosenberg et al., 2005 & Concept & Yes & HB & Health Insurance \\
\hline Royak-Schaler et al., 2003 & Variable & No & HB & Screening Procedures \\
\hline Silverman et al., 2002 & Concept & Yes & $\mathrm{HB}$ & $\begin{array}{l}\text { SES and Healthy } \\
\text { Behavior: Smoking } \\
\text { and Diabetes for } \\
\text { Males; Alcohol and } \\
\text { BMI for Females }\end{array}$ \\
\hline Singh et al., 2004 & Concept & Yes & SES & SES \\
\hline Selvin and Brett, 2003 & Concept & Yes & SES & $\begin{array}{l}\text { Primary Care } \\
\text { Physician; Health } \\
\text { Insurance }\end{array}$ \\
\hline Thatai et al., 2004 & Variable & No & $H B ; R G$ & $\begin{array}{l}\text { Healthy Behavior, } \\
\text { Biological Differences } \\
\text { in reactions to pharm, } \\
\text { Screening Procedures }\end{array}$ \\
\hline Young and Severson, 2005 & Concept & Yes & $\mathrm{HB} ; \mathrm{SC}$ & $\begin{array}{l}\text { Screening Procdures; } \\
\text { Education on Health } \\
\text { Practices }\end{array}$ \\
\hline Vallerand et al., 2005 & Variable & No & $\mathrm{HB}$ & $\begin{array}{l}\text { Ed on Pain } \\
\text { Mangagement; } \\
\text { Physician-Patient } \\
\text { Relationship }\end{array}$ \\
\hline
\end{tabular}




\section{Curriculum Vitae}

NAME Oliver Eugene Rollins, Jr.

\section{EDUCATION}

Master of Arts

University of Louisville

Department of Pan-African Studies, Spring 2007 (Current)

Major: Pan-African Studies, African American Concentration

Advisor: Theresa Rajack-Talley

Bachelor of Science

University of Houston

Department of Biology and Biochemistry, Summer 2005

Major: Biology

Minor: African American Studies

\section{RESEARCH/TEACHING INTERESTS}

African American Issues of Health and IIIness, HIV/AIDS, Youth and Violence, Medical Sociology: Theory and Research, Theory in African American Studies, African American Youth Culture

\section{ASSISTANTSHIPS/SCHOLARSHIPS}

University of Louisville

University of Louisville Graduate School/Dept. of Pan-African Studies

Ethnic Minority Graduate Fellowship 2006-2007

University of Louisville

Pan-African Studies Department

Graduate Assistantship 2005-2007 


\section{PRESENTATIONS}

"Health Inequalities: An Unspoken form of Violence," National Council for Black Studies $31^{\text {st }}$ Annual National Conference, San Diego, CA, March 2007

"HIV/AIDS in the African Diaspora," Saturday Academy Community Form sponsored by the University of Louisville's College of Arts and Sciences, Cheri Bryant Hamilton (District 5 Metro Councilwoman), the Jefferson County Public Schools, the Louisville Urban League, and the Kentucky Center for African

American Heritage, Louisville, KY, May 2006

"Freeing the Captive Mind and Striving for Liberation: An Afrocentric Investigation of Optimal Consciousness as Voiced through Hip Hop," National Council for Black Studies $30^{\text {th }}$ Annual National Conference, Houston, TX, March 2006

\section{AWARDS/ORGANIZATIONS}

President of Pan-African Graduate Student Association, University of Louisville, May 2006 - Present

Member of Association of Black Students, University of Louisville, August 2006 - Present

$1^{\text {st }}$ Place recipient in the Graduate Division, Student Essay Contest sponsored by the National Conference for Black Studies, March 2007

Recipient of International Studies Scholarship, College of Arts and Science, University of Louisville, Summer 2006 Trinidad and Tobago

$2^{\text {nd }}$ Place recipient in the Graduate Division, Student Essay Contest sponsored by the National Conference for Black Studies, March 2006

Treasurer of Pan-African Graduate Student Association, University of Louisville, August 2005 - May 2006

$3^{\text {rd }}$ Place recipient in the Undergraduate Division, Student Essay Contest sponsored by the National Conference for Black Studies, March 2005 


\section{GRADUATE COURSEWORK}

\section{MA Courses and Instructors}

Theories and Issues in Pan-African Studies

Dr. Denise Martin

Seminar on Black Culture

Social Justice Movements 1920-1960

Dr. Yvonne Jones

Pan-African Research Methods

Prof. Ann Braden

Advanced Seminar on Race

Dr. Theresa Rajack-Talley

Pan-African Social Thought

Dr. J. Blaine Hudson

Dr. Ricky L. Jones

Field Study - Trinidad and Tobago

Dr. Theresa Rajack-Talley

Seminar in Sociological Theory

Dr. Patricia Gagne

Sem. on Slavery and Slave Trade

Dr. J. Blaine Hudson

Sem. on Social Stratification

Dr. Clarence Talley

Sem. in Sociology Research Methods

Dr. John H Rieger

Minorities in Medicine

Dr. Nancy Potter

Research in Medical Sociology

Dr. Clarence Talley 


\section{REFERENCES}

Theresa Rajack-Talley, PhD

Associate Professor

Department of Pan-African Studies

Room 439 Strickler Hall

University of Louisville

Louisville, KY 40292

502-852- 4192 phone

502-852- 5954 fax

tatall01@louisville.edu

Ricky L. Jones, PhD

Associate Professor and Chair

Department of Pan-African Studies

Room 446 Strickler Hall

University of Louisville

Louisville, KY 40292

502-852- 5506 phone

502-852- 5954 fax

ricky.jones@louisville.edu

James L. Conyers, PhD

Director of African American Studies Program

University Professor of African American Studies

Room 632 Agnes Arnold Hall

University of Houston

Houston, TX 77024

713-743-2813 phone

713-743-2818 fax

iconyers@uh.edu 
Denise Martin, PhD

Assistant Professor

Department of Pan-African Studies

Room 438 Strickler Hall

University of Louisville

Louisville, KY 40292

502-852- 0003 phone

502-852- 5954 fax

denise.martin@louisville.edu

Clarence R. Talley, PhD

Associate Professor

Department of Sociology

Room 103 Lutz Hall

University of Louisville

Louisville, KY 40292

502-852-0838 phone

502-852-0099 fax

ctalley@louisville.edu 